\title{
EXPLORATION OF IMPORTANT ENVIRONMENTAL DETERMINANTS OF FLOWERING PHENOLOGY IN THE WESTERN HIMALAYAN FORESTS OF DHIRKOT, AZAD JAMMU AND KASHMIR, PAKISTAN
}

\author{
KHALID, N. ${ }^{1}-$ KHAN, A. M. ${ }^{1,2^{*}}-$ QURESHI, R. ${ }^{1}-$ SAQIB, Z. ${ }^{3}-$ ZAHID, N. ${ }^{4}-$ BUSSMANN, R. W. ${ }^{5}$ \\ ${ }^{I}$ Department of Botany, Pir Mehr Ali Shah Arid Agriculture University, Rawalpindi, Pakistan \\ ${ }^{2}$ Department of Botany, Govt. Hashmat Ali Islamia Associate College Rawalpindi, Pakistan \\ ${ }^{3}$ Department of Environmental Science, International Islamic University, Islamabad, Pakistan \\ ${ }^{4}$ Department of Botany, Mirpur University of Science \& Technology, 10250 Mirpur, AJ\&K, \\ Pakistan
}

${ }^{5}$ Department of Ethnobotany, Institute of Botany, Ilia State University, Tbolisi, Georgia

*Corresponding author

e-mail: arshadbotanist@gmail.com; phone:+92-333-521-7235

(Received $1^{\text {st }}$ Aug 2021; accepted 28 ${ }^{\text {th }}$ Oct 2021)

\begin{abstract}
The flowering phenology of plants is influenced by the unique set of environmental variations, and therefore, elucidation of important driving factors is important. The study area of Dhirkot (western Himalaya, Pakistan) is explored to record the interactions among the flowering phenology of the vascular plants and current climate along the temporal gradient from March-2015 to February-2018. A total of 38 randomly selected representative sites were visited to record the timing of flowering response and compared with mean monthly climatic data. Multivariate classification and ordination tools were used to analyze the data. The results revealed that majority $(185 \mathrm{spp} ; 68 \%)$ of plant species passes through thier flowering phase in the month of July. Canonical correspondence analysis (CCA) results depicted that about $63.7 \%$ of the phenological variations were explained by the monthly explanatory climatic variables, and mean minimum temperature, precipitation, wind speed and soil moisture were significantly (p-adj. <0.05) important. Pseudo-canonical correlation of the first three CCA axes was found higher than 0.8 which depicted that the selected variables were important determinants. This study concluded that predicted future temperature increase might alter the phenological responses, and prove to be devastating for valuable plant species of this unique and very delicate western Himalayan ecosystem.
\end{abstract}

Keywords: floral diversity, life forms, climatic variations, flowering events, multivariate analysis

\section{Introduction}

The word phenology is derived from the Greek word phainomai, which means "to appear". It is the study of the timing of life events of plants (Vashistha et al., 2009). Phenological events attract special attention when the normal pattern deviates, e.g. out of season flowering. Phenological studies are important to understand the interaction of species and community function, just like many other temporal and spatial aspects (Fenner, 1998). Flowering phenological studies observe the duration and timing of flowering, and temporal and spatial variations in the number of flowers in response to different environmental gradients (Rathcke and Lacey, 1985). The term phenology is used in ecology more generally to designate the period of any seasonal or cyclic phenomena, including the dates of last appearance (Menzel et al., 2006; Mier, 2007). 
Changes in phenological events are closely related to climatic variations (Bertin, 2008) and such changes can alter the functioning of ecosystem (Parmesan, 2006; Calinger et al., 2013) and ecological interactions such as those amongst plants and pollinators (Forrest, 2015; Kharouba and Vellend, 2015) or plants and migratory birds (Both et al., 2006). Selection pressure is considered as long-term cause of timing of a life history event, which is the cause of plants idiosyncratic phenology. These pressures vary from biotic types such as seasonal presence of pollinators, dispersers and predators to abiotic constraints such as seasonally unfavorable temperatures and unpredictable rainfall (Fenner, 1998; Badeck et al., 2004; Neil and Wu, 2006).

Phenology is an extremely delicate indicator (Peñuelas et al., 2004; Williams and Abberton, 2004), and thermoperiodic and photoperiodic responses affect flowering time variations from species to species (Holway and Ward, 1965; Khan et al., 2018). Phenological and phenomenological differences of plants are due to the interaction between environment and genotype (Raunkiaer, 1934; Mooney and Billings, 1960; Khan et al., 2019a,b). The ability of some plant species to grow in either early or late growth seasons indicate their ability to survive in harsh environment say least water availability, and low or high temperature (Vashistha et al., 2009; Patel et al., 2010). Any species not responding to climate change might have a risk of shorter growing season as compared to active competitors (Cleland et al., 2012). It has been shown that species not responding to temperature variations have declined significantly in abundance over the past 150 years (Willis et al., 2008), while species adaptive in their phenology with increase of warming have better chance of survival (Cleland et al., 2012). This clearly indicates that temperature variations influence species' capacity of survival (Wang et al., 2018).

According to an estimate, a rise of about $0.74^{\circ} \mathrm{C}$ is detected in global surface temperature over the past century by International Panel on Climate Change (IPCC, 2007), and resulting glaciers melt, decrease of snow cover, rise in sea level and change in patterns of temperature, wind and rainfall. These fluctuations have likely profound biological effects affecting many taxa in the different geographical regions of the world (Parmesan and Yohe, 2003; Menzel et al., 2006; Parmesan, 2006). For instance, many spring plants now show early leafing and flowering time across the world (Chambers et al., 2013; Schwartz et al., 2013; Ge et al., 2015), while changes in autumn phenological phases are often less obvious, but might have far reaching effects (Menzel et al., 2006; Gill et al., 2015). These studies have shown that the plant phenology phases are important biological indicators of the climate change, and influence all including terrestrial ecosystems (Rosenzweig, 2007).

The Himalayan mountain range is described as "Water Tower of Asia", and its melting glaciers recharge the eight largest rivers in Asia. When compared to the rest of the world, the Himalayan region is facing a relatively more pronounced rise of temperature (Khan et al., 2018) and has been declared the most vulnerable region in the world (Shrestha et al., 2012). These climatic changes are one of the main causes for loss and changes in biodiversity, species composition, shifting of geographical ranges of species, high glacier melting, increase in number of glacial lakes, and associated socioeconomic changes (Chaudhary et al., 2011). The Kashmir Himalaya is well known all over the world for its pleasing beauty. It has been referred to as a 'Terrestrial Paradise' (Vigne, 1842). One of the dominant features contributing to the global distinction of Kashmir is the rich biodiversity that embellishes its entrancing landscapes (Lawrence, 1895). Various studies (Shaheen et al., 2011; Nazir et al., 2012; Faiz et al., 2014; Khan et al., 2015, 2016, 2018, 2019a,b) have reported the distribution pattern of plant species and 
communities, life forms, leaf size spectra and flowering phenology of the western Himalayan forests in different parts of Azad Jammu and Kashmir (AJ\&K), Pakistan. However, the western Himalayan forests of Dhirkot, AJ\&K, Pakistan have remained unexplored, especially related to plant species traits, including life forms, leaf size spectra, and flowering phenology and its determinants. Therefore, documentation of existing interaction among the prevailing climate and flowering phenology of Dhirkot area would help in saving the biodiversity, and explore the following un-answered questions:

1. What about the plant species richness, and composition of major floristic groups, and pattern of biological and leaf size spectra distribution?

2. When majority of vascular plant species enter in flowering phase?

3. How the vascular plant species flowering response is correlated with the current climate?

4. What are the number of statistically significant temporal groups linked to flowering phenological response of the vascular plant species?

5. Which climatic variables are the most influential determinants of the plant species flowering phenological response?

\section{Materials and Methods}

\section{Study area}

The study area of Dhirkot is a Tehsil of District Bagh, AJ\&K, Pakistan, in the western Himalayas, and located $132 \mathrm{~km}$ from the capital city of Islamabad. It lies between 73.50-73.69 East longitude and 33.90-34.13 North latitude, covering an area of $231 \mathrm{~km}^{2}$. The elevation ranges from 603 to $2639 \mathrm{~m}$ above sea level (masl). Dhirkot borders district Muzaffarabad in the north, district Poonch in the south, tehsil Harighel of district Bagh in the east, and the river Jhelum in the west (Fig. 1). The entire area is a mountainous terrain with generally sloping orientation from North-East to South-West, and covered with thick, green coniferous forests.

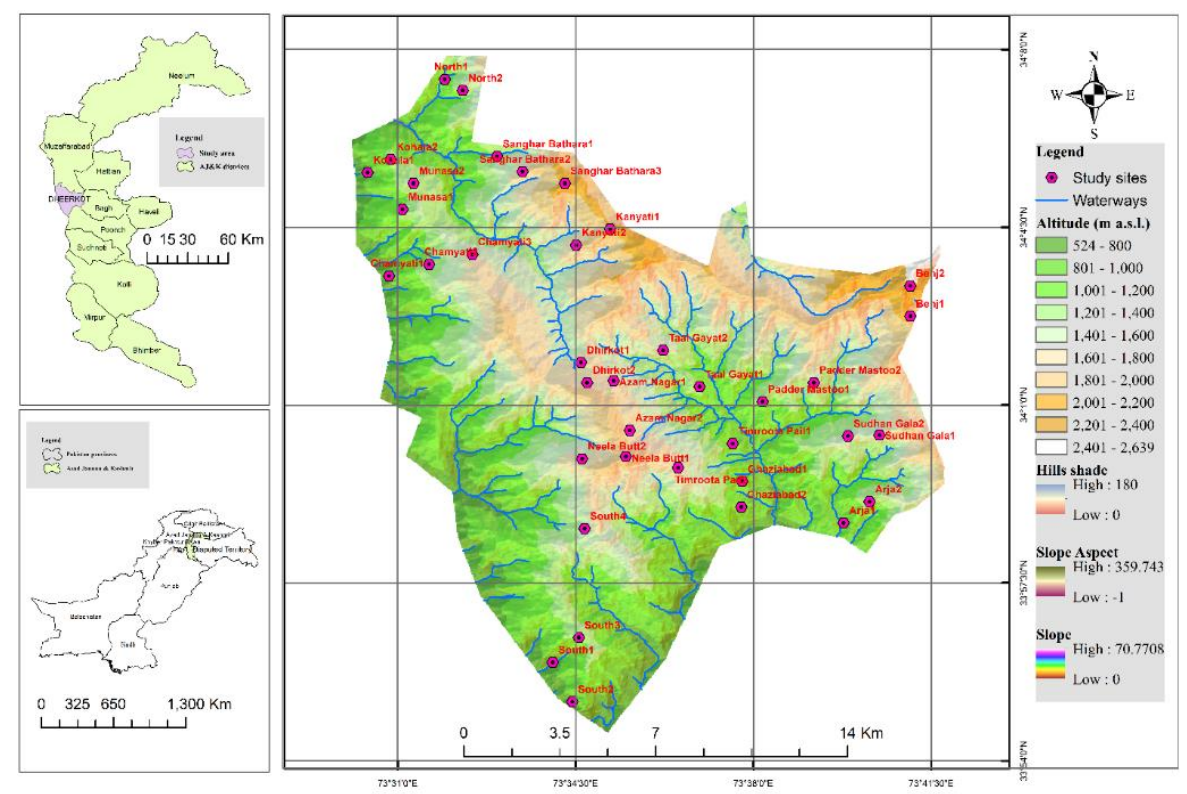

Figure 1. Map of the study area displaying study locations and topographic variations 
The forest vegetation of the study area is comprised of western Himalayan mixed temperate forests with dominance of Pinus wallichiana (Blue Pine) and Cedrus deodara (Deodar). The humid subtropical zone harbors Pinus roxburghii (Chir Pine) as abundant species (Fig. 2). A total of 15 bird and 20 mammal species are commonly encountered, including globally threatened species like leopard (Khan, 2002). The human population of the area is 36270 based on the population census results of 2017 (Anonymous, 2017). The majority of local communities has inadequate income resources and depends on agrobased activities for their livelihoods. The most important crops include maize, wheat and vegetables, with a major share of tomatoes and potatoes. As the study area is mountainous, terrace cultivation techniques are adopted, and the yield is significantly linked to rainfall patterns in the area.

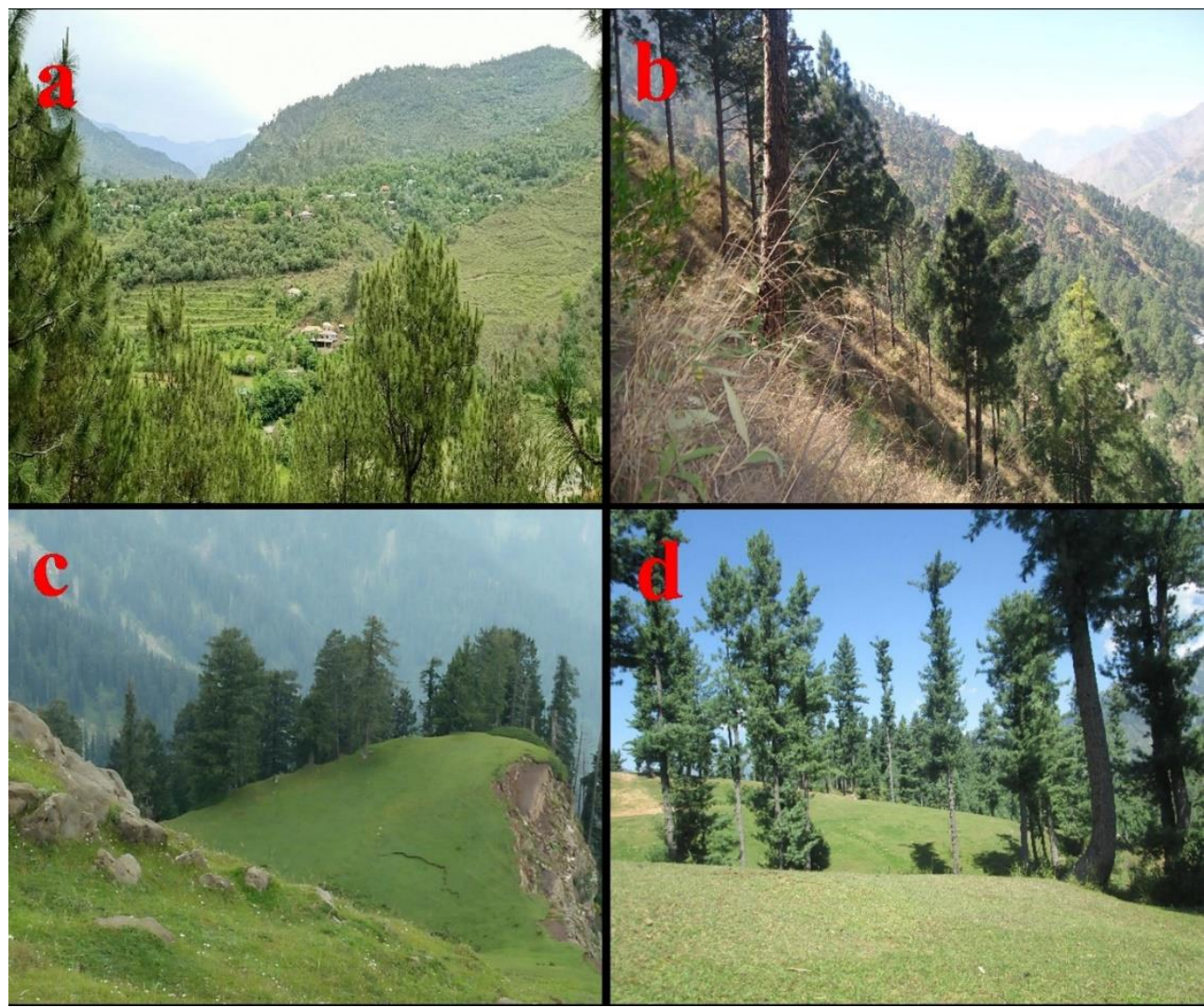

Figure 2. Diverse landscape of two elevation zones representing sampled microhabitats (a: subtropical broad leaved evergreen forest zone; $b$ : subtropical evergreen coniferous forest zone; c-d: Himalayan moist temperate forest zone

\section{Floristic and phenological data collection}

A total of 38 randomly selected sites (Fig. 1) of the study area are visited on monthly basis (Dates: $11^{\text {th }}-20^{\text {th }}$ ) from March 2015 to February 2018 (36 months) for collection of plant specimens, and to record the temporal variations in flowering response. The applied observation frequency is appropriate, and the same was also used by Khan et al. (2018). At each site, 3 plots of varying sizes (herbs: $2 \times 1 \mathrm{~m}$; shrubs: $10 \times 5 \mathrm{~m}$; tree: $20 \times 10 \mathrm{~m}$ ) were laid, and the presence/absence of each plant species (criterion; if more than $50 \%$ individuals of any recorded species are found passing through their flowering phase in 
the considered plot/month subsequently counted as present otherwise absent.) were recorded. All the collected plant specimens were pressed, dried and mounted on the standard sized herbarium sheets, followed by identification using Flora of Pakistan (http://www.efloras.org/) and other floristic literature (Nasir and Ali, 1970-1989; Ali and Nasir, 1989-1991; Ali and Qaiser, 1993-1995, 2000-2014). After identification, the binomials of each plant species and their family names were copied from the plant list (TPL) ver. 1.1 (http://www.theplantlist.org/) (TPL 2013) to avoid the use of illegitimate and synonymous binomials (Khan et al., 2015, 2016, 2018). The determined voucher specimens were deposited in the herbarium of Department of Botany, Pir Mehr Ali Shah Arid Agriculture University Rawalpindi, Pakistan for future reference and record. Additional information, including local names, Raunkiaer's biological spectra or life forms (Batalha and Martins, 2002; Khan et al., 2019b) and leaf size spectra (Cain and Castro, 1959) were also recorded for each plant species. Additionally, native or introduced status of each species is recorded along with thier abundance (frequency of occurrence among the studied sites) status and invassive-noninvassive capabilities.

Monthly flowering response (timing and duration) of each plant species is calculated by using the formula conveyed by Khan et al. (2015), and presented in Eq.1.

$$
\text { SFR }(\%)=\frac{\text { Species found in flowering in a month at all studied sites }}{\text { Total species found in flowering in all months and sites }} \times 100
$$

Where SFR is the monthly species flowering response of the studied plants. Subsequently, monthly responses were averaged to calculate the seasonal flowering response of each plant species say winter (November-February), spring (March-April), summer (May-mid July), monsoon (mid July-mid September), and autumn (mid September-October).

Family richness (FR) was calculated by using the formula (Eq.2) as conveyed by Khan et al. (2018).

$$
F R(\%)=\frac{\text { Species belong to a plant family }}{\text { Total species recorded in all months and sites }} \times 100
$$

\section{Climate data collection}

The climate of the area varies considerably on temporal scales. The month of January was recorded as the coldest month in the study area, and minimum temperature varied between -0.35-2 ${ }^{\circ} \mathrm{C}$ during 2015-2018, whereas the month of June was the hottest and maximum temperature varied from $31.32-34.04{ }^{\circ} \mathrm{C}$. The minimum precipitation received in the month of December (varied between 2.79-55.87 $\mathrm{mm}$ ) and the July was recorded as the wettest receiving maximum (381.29-625.72 mm) (Supplementary Data Table 2). The remote sensing based monthly climate data of precipitation, maximum and minimum temperature, specific humidity, soil moisture, wind speed, and short \& longwave radiation (36 months) of the study area (Dhirkot) was acquired from the United States National Centers for Environmental Prediction (US-NCEP) Climate Forecast System Reanalysis (CFSR) by using climate engine (https://app.climateengine.org/). The data source was CFSv2 19200 m (1/5-deg) daily reanalysis dataset, National Oceanic and Atmospheric Administration (NOAA) (Supplementary Data Table 2). The majority of study area receives precipitation in the form of snowfall from December to mid-March (Khan et al., 2018). 


\section{Statistical analyses}

The events of sporogenesis in pteridophytes, strobili development in gymnosperms and flowering in angiosperms were treated as flowering response during each of 36 months at 38 ranodomly selected sites. This response data was entered in Microsoft excel spreadsheets (species vs. month/seasons) as binary data matrix. The total number of plant species found in flowering in each month at all the study sites was calculated and correlated with remote sensing based climatic data by using $\mathrm{R}$ statistical package (R Core Team, 2015) to develop pairwise correlation, distribution and scatterplots (Khan et al., 2015, 2018). Hierarchical clustering (Distance: Correlation, Linkage: Ward) was developed using the package "pvclust" in the $\mathrm{R}$ statistical package. As the species flowering respose data is of binary (presence/absence) nature, detrended correspondence analysis (DCA), a unimodal unconstrained model, was selected to seek the gradient length in the binary compositional response data whereas CCA (a constrained unimodal ordination model) was performed to explore; how much variations in the response data were explained by the studied predictors, and what is their order of importance. Multicollinearity in the climatic variables was detected by observing the variance inflation factor values (VIFs) of each climatic variable, and a threshold value of $<5$ was selected to remove the highly collinear explanatory variables. If the overall CCA model results found significant ( $\mathrm{p}$-value $<0.002$ ), subsequently all the explanatory variables were further tested for their significance and order of importance by using permutation test via both simple (marginal) and conditional (net) term effects testing. All the p-values were corrected by using false discovery rate method. The ordination was performed by using Canoco software (Ter Braak and Smilauer, 2012).

\section{Results}

\section{Floristic categorization}

A total of 287 vascular plant species belonging to 219 genera and 77 plant families were recorded in the study area. The results of species categorization into major taxonomic groups depicted that there were 8 species $(2.79 \%)$ of pteridophytes, and distributed in 5 genera $(2.28 \%)$ and 3 families (3.9\%). A total of four species $(1.39 \%)$ of gymnosperms were recorded, and belong to 3 genera (1.37\%) and 2 families $(2.6 \%)$. The majority of plant species (275 species; 95.8\%) belong to angiosperms, and found distributed in 211 genera (96.34\%) and 72 plant families (93.5\%). Within the latter group, 59 plant species $(20.56 \%)$ belong to monocotyledons, and distributed in 46 genera $(21 \%)$ and 6 plant families $(7.8 \%)$ whereas, 216 species $(75.26 \%)$ belong to dicotyledons, and distributed in 165 genera (75.34\%) and 66 plant families (85.7\%) (Table 1).

Table 1. Floral composition of the major plant taxa in the study area

\begin{tabular}{c|c|c|c}
\hline Taxa & Families (percent) & Genera (percent) & Species (percent) \\
\hline Pteridophytes & $03(3.9 \%)$ & $05(2.28 \%)$ & $08(2.79 \%)$ \\
Gymnosperms & $02(2.6 \%)$ & $03(1.37 \%)$ & $04(1.39 \%)$ \\
Monocots & $06(7.8 \%)$ & $46(21 \%)$ & $59(20.56 \%)$ \\
Dicots & $66(85.7 \%)$ & $165(75.34 \%)$ & $216(75.26 \%)$ \\
Total & 77 & 219 & 287 \\
\hline
\end{tabular}


The study area was dominated by herbs (212 species; $73.86 \%)$, followed by shrubs (33 species; $11.49 \%$ ), trees (32 species; $11.15 \%$ ), and climbers group (10 species; $3.48 \%$ ) (Supplementary Data Table 1). The family richness (FR) results showed that Poaceae was the leading family with 41 species $(14.28 \%$ ), followed by Compositae (34 species, 11.84\%), Lamiaceae (22 species, 7.66\%), Leguminosae (14 species, 4.87\%), Cyperaceae (11 species, 3.83\%), Rosaceae (10 species, 3.48\%), Amaranthaceae and Polygonaceae (8 species each, $2.79 \%$ ), and Solanaceae (7 species, $2.44 \%$ ), whereas the remaining plant families were represented by $\leq 6$ species (Supplementary Data Table 1).

The results of biological (life form) classification of recorded plant species showed the dominance of therophytes with 106 species (36.93\%), followed by hemicryptophytes (67 species, 23.34\%), phanerophytes (65 species, 22.99\%), geophytes (22 species, $7.66 \%$ ), chamaephytes (16 species, 5.57\%), and lianas (10 species, 3.48\%). The phanerophytes were further distributed into nanophanerophytes (29 species, 10.10\%), mesophanerophytes (21 species, 7.32\%), microphanerophytes (10 species, 3.48\%), and megaphanerophytes (6 species, 2.09\%) (Fig. 3). The leaf size spectrum of the recorded vascular flora was dominated by microphylls (137 species, 47.74\%), followed by mesophylls (69 species, 24\%), nanophylls (56 species, 19.51\%), leptophylls (19 species, 6.62\%), and macrophylls (6 species, 2.09\%) (Fig. 4).

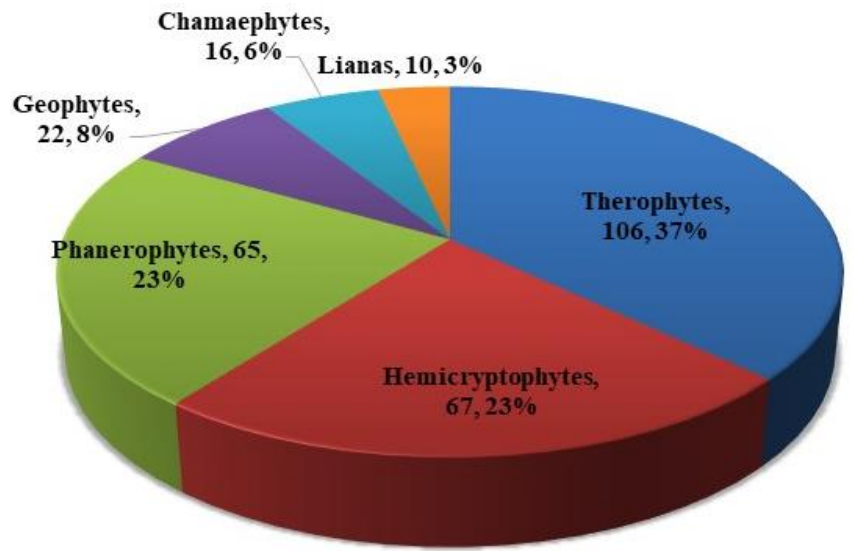

Figure 3. Graph depicting the distribution of recorded vascular plant species into different life form classes

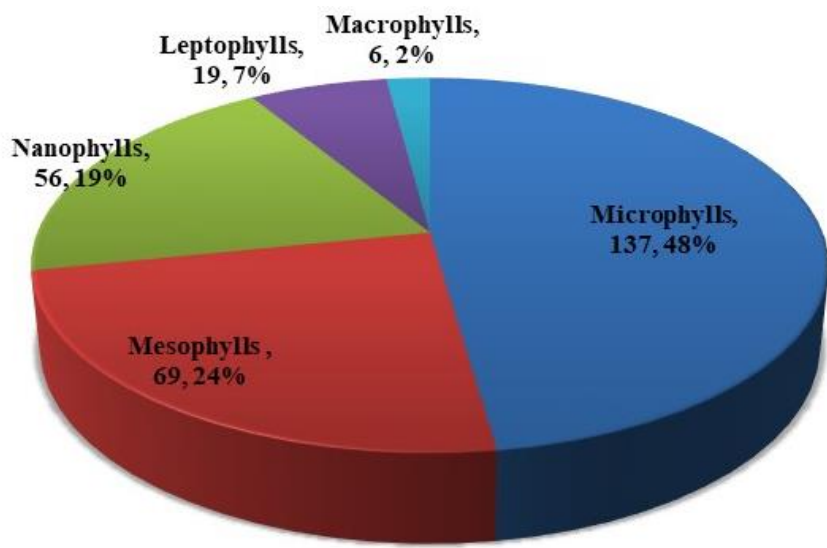

Figure 4. Graph depicting the distribution of recorded vascular plant species into different leaf size classes 
A total of 234 plant species $(81.5 \%)$ were native of the area, and $53(18.5 \%)$ are introduced ones. Similarly, on the basis of frequency of occurrence of the recorded plant species among the studied sites, $110(38.3 \%)$ were very common, $101(35.2 \%)$ were common, $55(19.2 \%)$ were rare, and $21(7.3 \%)$ were very rare. A total 48 plant species (16.7\%) were recorded as highly invassive in the study area (Supplementary Data Table 1).

\section{Flowering phenology}

The results of flowering response of the recorded plant species showed that majority of plant species (185 species, 64.46\%) were in flowering phase during the month of July, followed by August (182 species, 63.41\%), June (167 species, 58.19\%), and September (145 species, 50.52\%). The least response was observed in the month of December (14 species, 4.88\%) and January (13 species, 4.53\%) (Fig. 5). The flowering phenology response results indicated that most of the plant species go through their initial reproductive phase (flowering) from March to October.

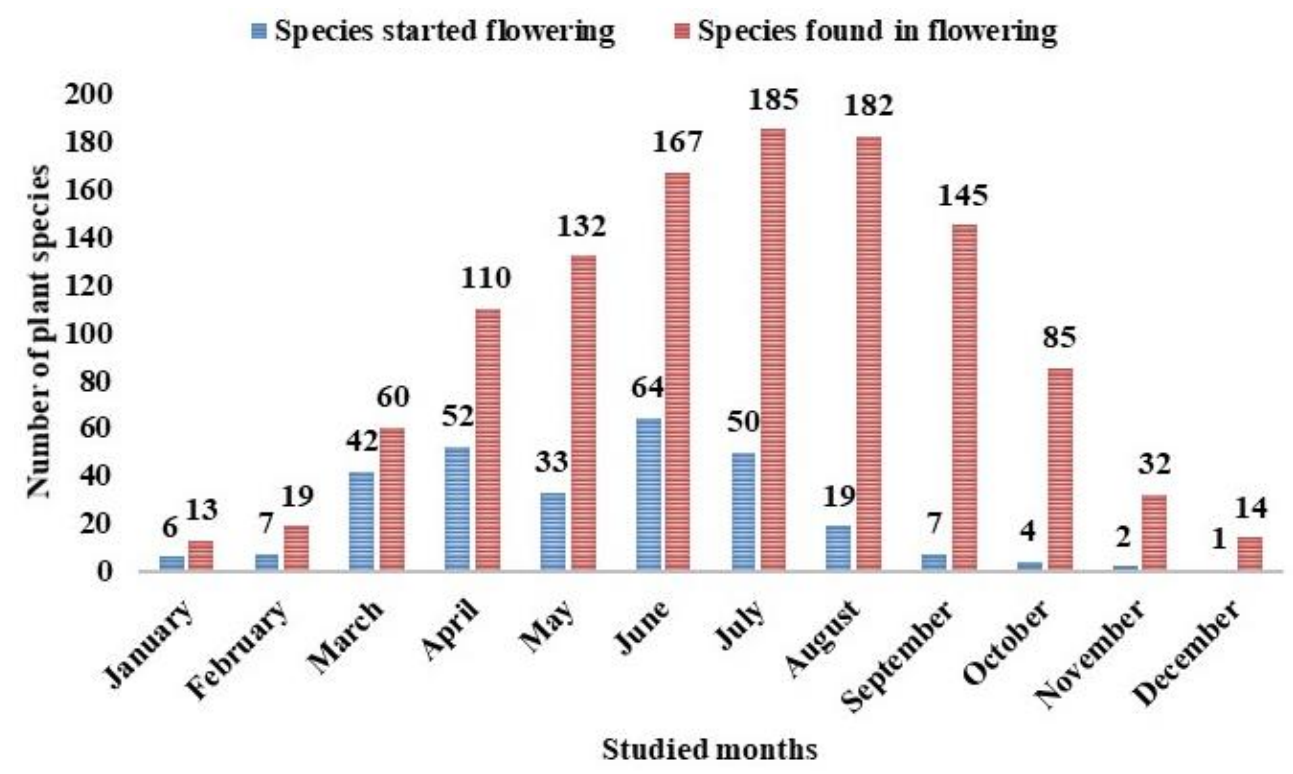

Figure 5. Graph depicting the variations in flowering phenology of the recorded vascular plant species during studied months (each monthly value represent the cumulative number of 36 studied months/3 years: March-2015 to February-2018)

As far as the results of initiation of flowering event during the studied months are concerned, majority of plant species were entered in flowering phase in the month of June (64 species, 22.3\%), followed by April (52 species, 18.12\%), July (50 species, 17.42\%), and March (42 species, 14.63\%), whereas, least species were found entering in their flowering phase in the month of December ( 1 species, $0.35 \%)$, followed by November (2 species, 0.7\%), October (4 species, 1.39\%), and January (6 species, 2.09\%) (Fig. 5).

The results of Pearson's correlation and its significance depicted that the total plant species found in flowering phase in different months (SFR\%) was strongly correlated $(r>0.8)$ with the mean monthly values of five different climatic variables. These includes mean minimum temperature $(\mathrm{r}=0.93)$, shortwave radiation $(\mathrm{r}=0.93)$, longwave radiation $(r=0.92)$, mean maximum temperature $(r=0.89)$, and mean specific humidity $(r=0.88)$. 
Similarly, precipitation was found moderately positively correlated $(r=0.49)$. A strong negative correlation was observed with wind speed $(r=-0.69)$, whereas no correlation of flowering abundance was observed with the soil moisture of the study area (Fig. 6).

Pearson's correlation

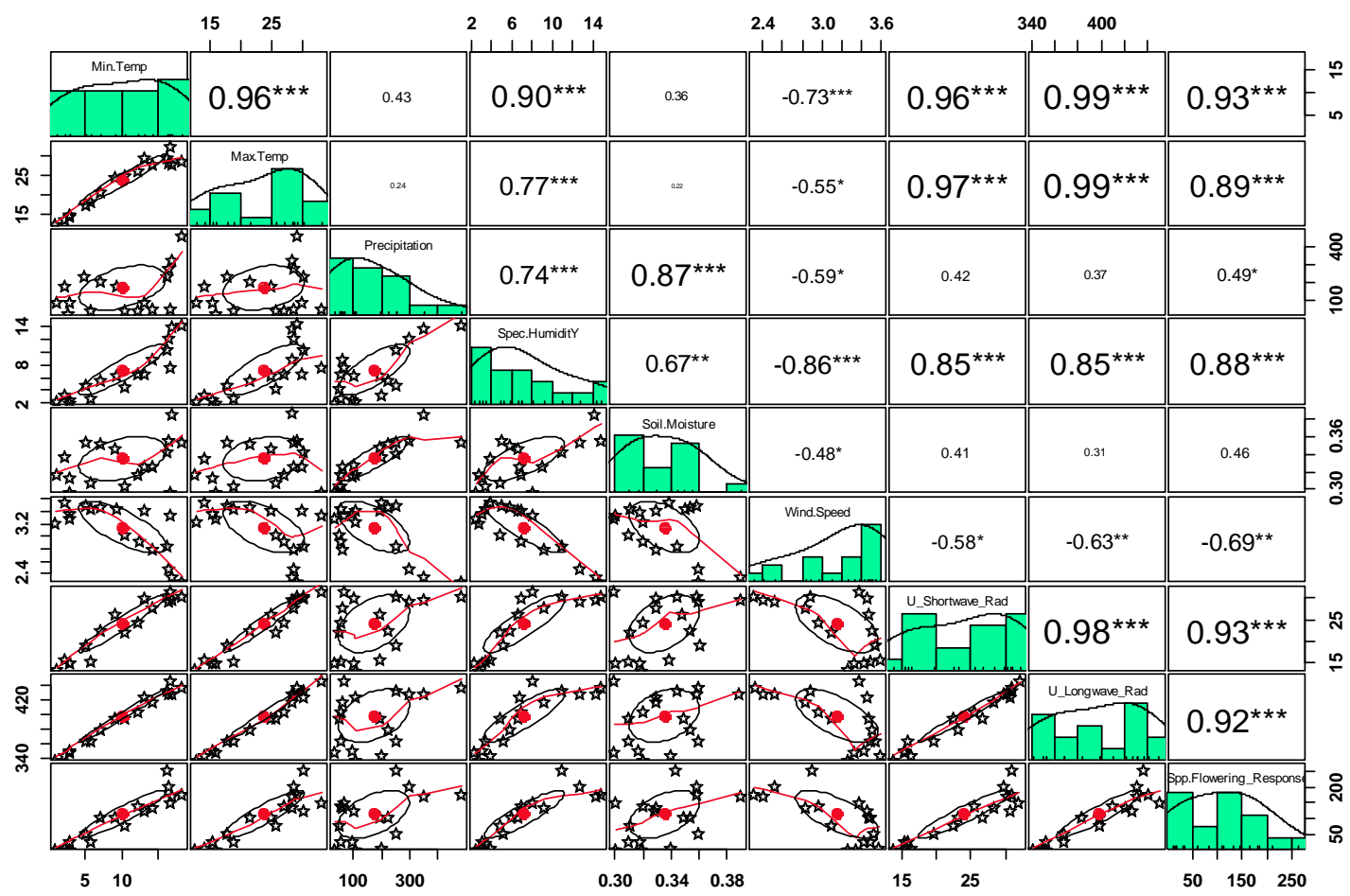

Figure 6. Pearson correlation and its significance of climatic and SFR $(n=17$; months $=12 \&$ seasons $=5$ ) variables. The distribution of each studied variable is shown on the diagonal, the bottom of the diagonal has bivariate scatter plots with a fitted line, and ellipses are displayed.

Top of the diagonal has the correlation values coupled with significance levels as stars, representing p-values (“***” $\leq 0.001$; “**” $\leq 0.01$; “*” $\leq 0.05$; “” $>0.05$ )

Similarly, the month of June is found strongly correlated with the summer season on the basis of plant species flowering response. The months of July and August were detected as representative of monsoon season when the majority of flowering responses were observed. April was the main representative of the spring season which last from March to May. The winter season with least flowering response was primarily comprised of the months from November to February (Fig. 7).

Hierarchical clustering of months and seasons results were closely related to the pairwise correlation (Fig. 7). The dendrogram tree depicted that there were four significantly ( $\mathrm{p}$-value $<0.05$ ) different groups of months and seasons in the study area based on timing of plant species flowering response. The values given in green and red font colour above each cluster represent the approximately bootstrapped probability (BP \%) and unbiased (AU \%) p-values respectively. Likewise, the grey colored values below each cluster show the order of clustering (Fig. 8). 


$$
-310 \text { - }
$$

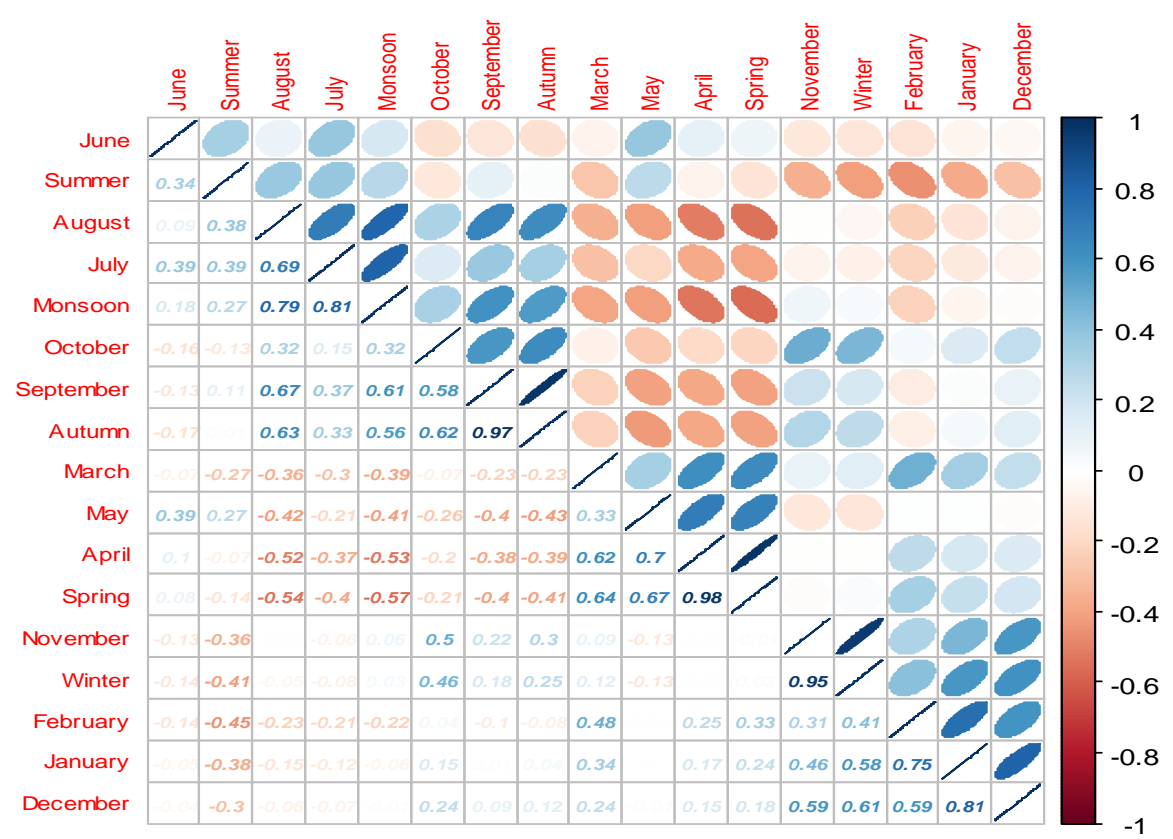

Figure 7. Pairwise correlation plot of months and seasons based on plant species flowering phenological response ( $n=287$ plant species)

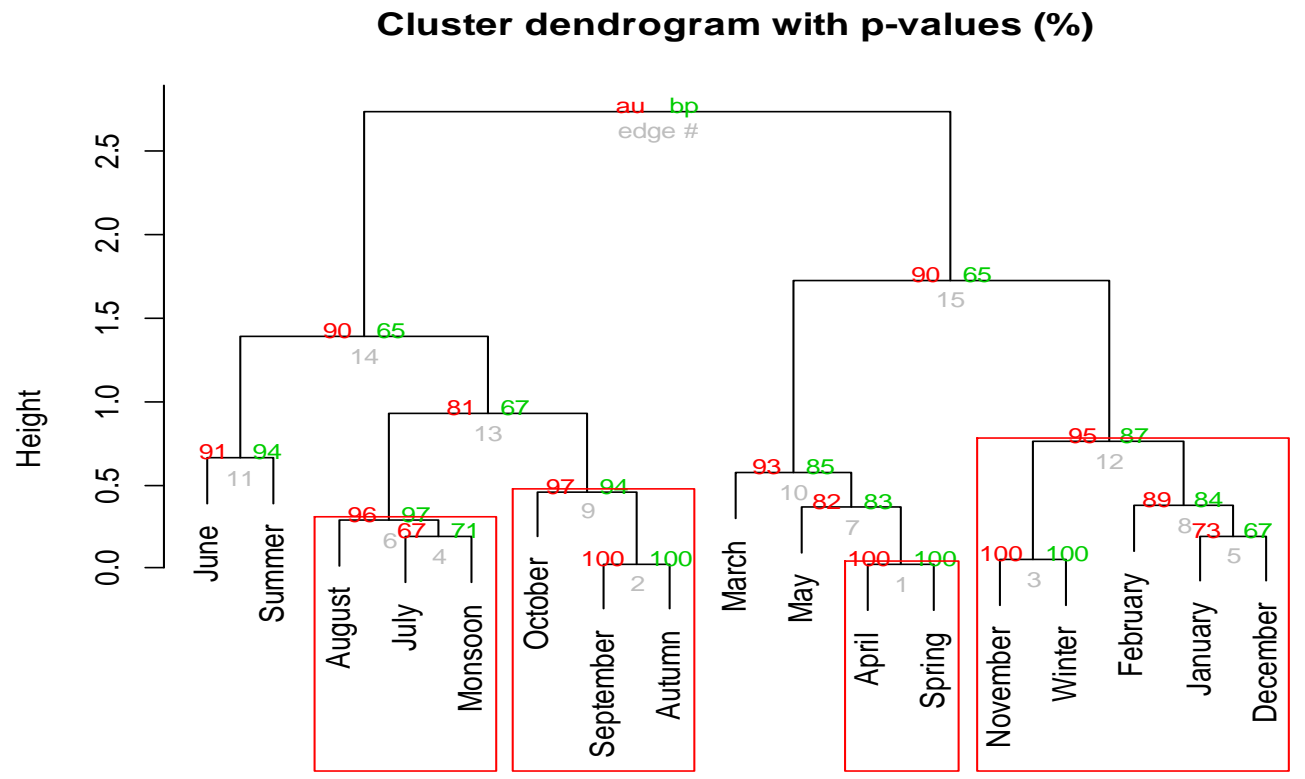

Figure 8. Hierarchical clustering tree of months and seasons (distance method: correlation; linkage method: Ward) with AU/BP\% values based on plant species flowering phenological response (Red colored rectangle around the clusters represents significant ( $p$-value $\leq 0.05$ ) response difference)

\section{Ordination analysis}

The DCA results showed that the gradient length in the response data was above 4 SD (standard deviation of species turnover) for the first two DCA axes, hence, depicted that 
use of a unimodal like DCA is more appropriate in this study than say principal component analysis (PCA: a linear model). The DCA results also confirmed the results of hierarchical clustering, and the same four groups are found well distincntly distributed in the ordination space. After removal of highly collinear, final CCA model is comprised of four predictors, including minimum temperature, wind speed, precipitation, and soil moisture ( $25 \mathrm{~cm}$ below the soil surface). A total inertia of 1.38 was recorded in the flowering phenology response data, and about $63.7 \%\left(\mathrm{R}^{2}: 0.637\right)$ variations were explained by the explanatory variables, and the adjusted explained variations were $51.6 \%$ (adjusted $\mathrm{R}^{2}$ : 0.516). The first two CCA axes cumulatively explained about $55 \%$ variations. A significantly high pseudo-canonical correlation $(r>0.8)$ value was observed for the first three CCA axes which depict that the selected predictors were important determinants, and there is no single important climatic gradient rather all the four were important in one way or another.

The overall CCA model results were significant (pseudo-F: 2.7; p-value <0.002), and based on simple term effects testing, the mean minimum temperature was detected as leading driver (explained variations: 27.2\%; p-value [adj]: 0.004) of the flowering phenological response. It was followed by wind speed, precipitation and soil moisture. In case of conditional (unique) term effect testing, precipitation surpassed wind speed in order of importance. The study area received maximum precipitation in the months July and August during monsoon, and the same months/season were found highly suitable for flowering by the vascular plant species. These results are confirmed by CCA, and precipitation was detected as second most important determinant followed by wind speed which might be another important determinant as prerequisite for successful pollination of many species. Similarly, soil moisture was another influential determinant. The CCA numerical and graphical results are presented in Table 2 and Fig. 9, respectively. The CCA biplot of months/seasons and climatic predictors showed that minimum temperature was highly correlated with the months of June, July and August, and Monsoon season, whereas wind speed was relatively higher than the average for spring season including March and April months (Fig. 9).

Table 2. Summary of canonical correspondence analysis results and contribution of climatic variables in driving of flowering phenological response

\begin{tabular}{ccccc}
\hline Statistic & Axis 1 & Axis 2 & Axis 3 & Axis 4 \\
\hline Eigenvalues & 0.4545 & 0.3134 & 0.0598 & 0.0529 \\
Explained variation (cumulative) & 32.86 & 55.51 & 59.84 & 63.67 \\
Pseudo-canonical correlation & 0.9781 & 0.9449 & 0.8159 & 0.7173 \\
Explained fitted variation (cumulative) & 51.61 & 87.2 & 93.99 & 100 \\
\hline & Simple Term Effects: & & & \\
\hline Name & Explains $\%$ & pseudo-F & P & P(adj) \\
\hline Min. Temp $\left({ }^{\circ} \mathrm{C}\right)$ & 27.2 & 5.6 & 0.002 & 0.004 \\
Wind speed $(\mathrm{m} / \mathrm{sec})$ & 23.5 & 4.6 & 0.002 & 0.004 \\
Precipitation $(\mathrm{mm})$ & 7 & 1.1 & 0.33 & 0.438 \\
Soil moisture $(25 \mathrm{~cm} ;$ in fraction) & 5.8 & 0.9 & 0.438 & 0.438 \\
\hline Name & Conditional Term Effects: & & \\
\hline Min. Temp $\left({ }^{\circ} \mathrm{C}\right)$ & Explains $\%$ & pseudo-F & $\mathrm{P}$ & $\mathrm{P}(\mathrm{adj})$ \\
Precipitation $(\mathrm{mm})$ & 27.2 & 5.6 & 0.002 & 0.008 \\
Wind speed $(\mathrm{m} / \mathrm{sec})$ & 15.9 & 4.9 & 0.004 & 0.008 \\
Soil moisture $(25 \mathrm{~cm}$; in fraction) & 14.6 & 3.5 & 0.008 & 0.01067 \\
\hline
\end{tabular}



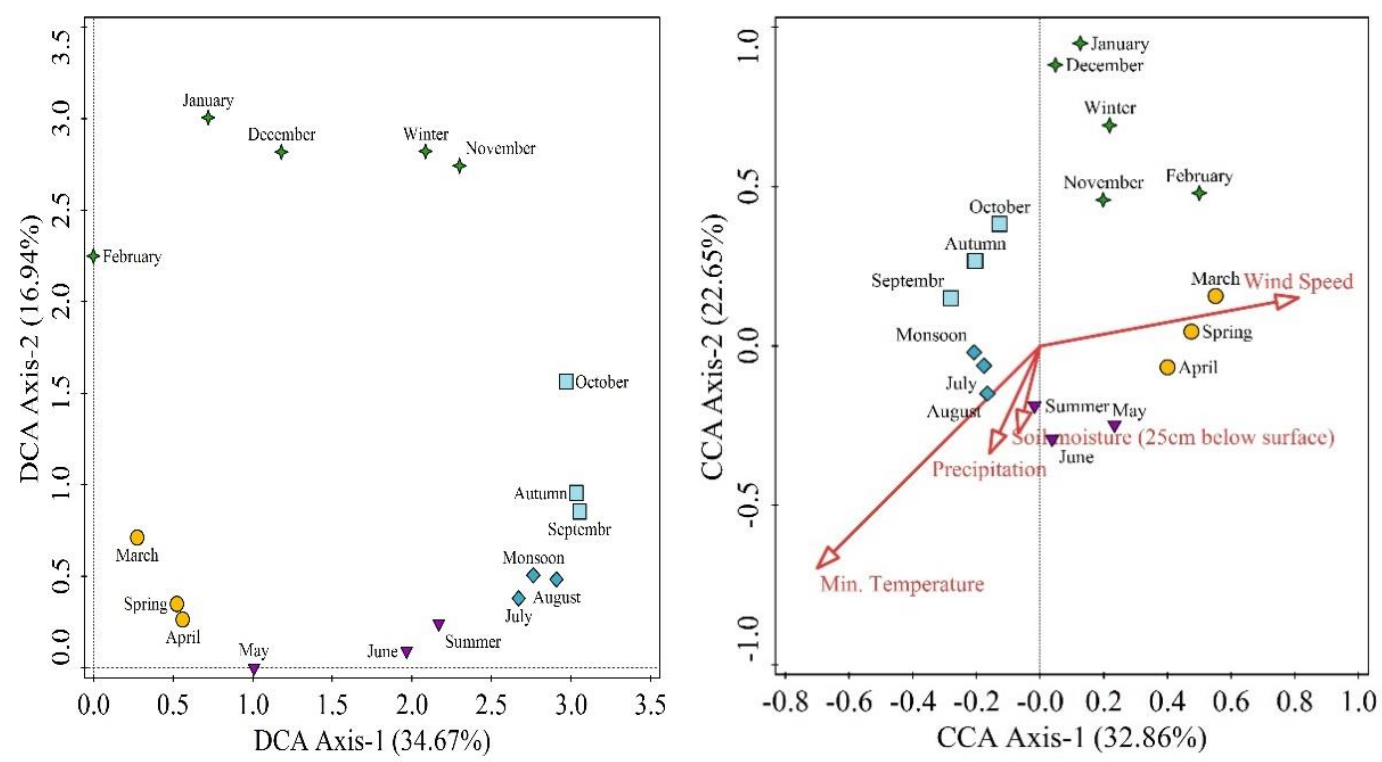

Figure 9. DCA scatterplot and CCA biplot presenting the distribution pattern of months and seasons based on flowering response of plant species, and role of climatic variations respectively

\section{Discussion}

\section{Floristic classification and its importance}

The study area of Dhirkot (AJ\&K), Pakistan is a mountainous terrain, part of western Himalaya, and rich in floristic diversity. The present study was conducted to record the floristic composition of the area along with various attributes including biological spectra, leaf size spectra, flowering phenology and flowering phenological response of the vascular plant species along the prevailing climatic gradients.

A total of 287 vascular plant species were documented, and Poaceae was the leading family followed by Compositae and Lamiaceae. The present work showed a striking similarity with the floristic composition of Qalagai hills, Kabal valley, Swat (Ilyas et al., 2013) who also reported Poaceae (22 spp.) as dominant plant family followed by Compositae (16 spp.) and Lamiaceae (14 spp.). Similarly, Shaheen et al. (2015) also reported the same order of family richness from the western Himalayan subtropical forest stands of Kashmir. Other results similar to our findings include the work of Khan et al. (2014) from Shahbaz Garhi, district Mardan, Pakistan, Tanvir et al. (2014) from district Bagh, AJ\&K, Pakistan, Khan et al. (2015) from district Kotli, AJ\&K, Pakistan, and Khan et al. (2017) from Swat Ranizai, district Malakand, Khyber Pakhtunkhwa, Pakistan. The dominance of Poaceae and Compositae are due to their wide ecological amplitude within diverse habitat (Ibrahim et al., 2019). The common presence of grazing animals contributes to the spread of grasses. Grasses often quickly colonize any area (Attenborough, 1984). Similarly, Compositae is the largest family within angiosperms and possibly it is the most successful in evolutionary traits. Plant species of Compositae and Lamiaceae are economically and medicinally important in the western Himalaya, so people might transport them from one place to another resulting their quick spread to newly available habitats. 


\section{Biological spectra and its significance}

The biological (life form) classification results depicted the dominance of therophytes followed by hemicryptophytes, phanerophyte, geophytes, Chamaephytes, and lianas. These results closely resemble with the results of Qalagai hills, Kabal valley, SwatPakistan (Ilyas et al., 2013), who reported therophytes as dominant followed by hemicryptophytes and macrophanerophytes. Other similar results include the studies conducted by Khan et al. (2014) from Shahbaz Garhi, district Mardan, Pakistan, Shaheen et al. (2015) from the western Himalayan subtropical forests of Kashmir, Khan et al. (2019c) from Mandan, district Bannu, Pakistan, Ishaq et al. (2019) from Derikot Selai Pattay district Malakand, Pakistan, and sililarly match with many otheres (Malik, 1986; Malik and Malik, 2004; Ajaib et al., 2008; Nazir et al., 2014). Although, life form can be used as an indicator or response towards the climate, Raunkiaer (1934) suggested that anthropogenic disturbances also contribute towards life form variations. Therophytes are usually considered as characteristics of harsh environmental conditions and hemicryptophytes as indicators for the temperate region with cold humid climate (Cain and Castro, 1959; Shimwell, 1971; Batalha and Martins, 2002). Hence, the dominance of therophytes in the study area may also be due to population pressure, over grazing, land modification for terrace cultivation and deforestation (Shehzad et al., 1999; Ilyas et al., 2013). In addition, winter drought might be an important factor continuously pushing plant species to a therophytes life form, and the presence of perennating structures just under the soil surface (hemicryptophytes) to pass the unfavorable environment is also common. The dominance of hemicryptophytes might be due to the extreme cold environment in winter, as well as heavy biotic stress due to overgrazing and deforestation (Nazir et al., 2014). On the other hand, the reasonable contribution of phanerophytes showed that the study area provide an ample environment for Himalayan forest tree species, e.g., Pinus wallichiana A.B. Jacks., Pinus roxburghii Sarg., Cedrus deodara (Roxb. ex D. Don) G. Don, Quercus baloot Griff., Quercus incana Bartram, Acacia nilotica (L.) Delile (Khan et al., 2017). Overall the thero-hemicryptophytic flora of the study area shows adaptations to avoid the harsh and long winter season, although the conifers and few sclerophyllous plant species remain active around the year (Ilyas et al., 2013).

\section{Leaf size spectra and its significance}

The leaf size spectrum of the vascular flora was dominated by microphylls, followed by mesophylls, nanophylls, leptophylls, and macrophylls. Our results resemble with the study conducted in Swat Ranizai, district Malakand, Khyber Pakhtunkhwa, Pakistan (Khan et al., 2017). Similarly, Khan et al. (2011) reported the dominance of microphylls followed by mesophylls and nanophylls from Darra Adam Khel, Khyber Pakhtonkhwa, Pakistan. In addition, Ishaq et al. (2019) from Derikot Selai Pattay district Malakand, Pakistan, Khan et al. (2014) from Shahbaz Garhi, district Mardan, Pakistan also reported the dominance of microphylls, and in many other studies (Amjad, 2012; Ilyas et al., 2013; Ibrahim et al., 2019). Leaf sizes of microphylls, mesophylls and nanophylls classes dominate in the flora of Dhirkot. Large sized leaves (mesophylls and macrophylls) are characteristic of wet warmer climates coupled with high precipitation, while the dominancy of small sized leaves (microphylls) are common in degraded dry habitats coupled with cold climates. The appearance of microphylls and nanophylls in the study area might be an adaptation to arid conditions. The majority of study area faces a long 
drought period, especially during autumn and winter). Leaf size generally increases with increasing rainfall and declines with increasing irradiance and elevation (Khan et al., 2014). Therefore, the dominance of microphylls was positively associated with the increasing altitude, as also found by (Dewald and Steiner, 1986; Khan, 2013). Microphylls and nanophylls are the features of temperate regions (Cain and Castro, 1959; Shimwell, 1971), and climatically the study area of Dhirkot is also situated in the temperate zone. The dominance of mesophylls may be due to reasonable monsoon rainfall, and some unique microhabitats harboring rare and valuable plant species in the area (Fig. 10).

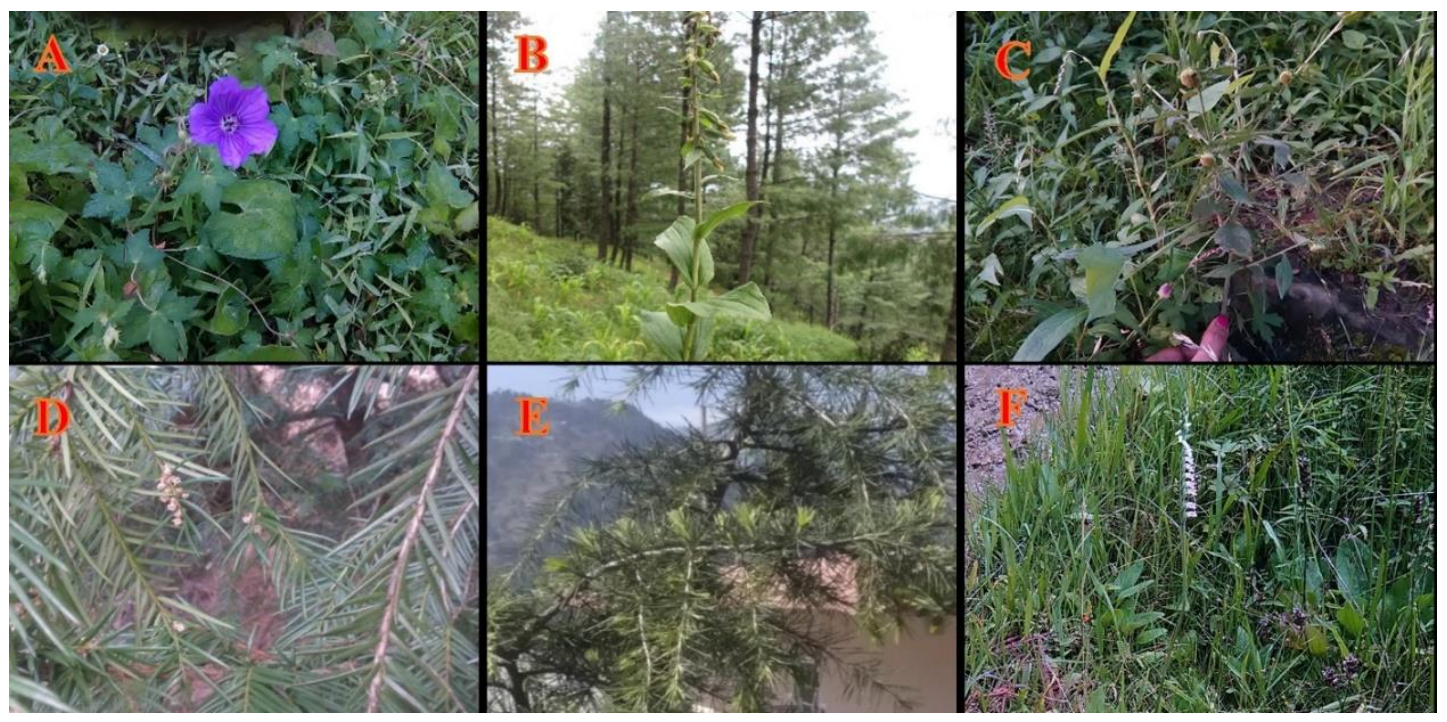

Figure 10. A figure displaying some rare vascular plants in flowering phase (A) Geranium wallichianum (B) Epipactis helleborine $(C)$ Carpesium cernuum (D) Taxus wallichiana and $(E)$ Cedrus deodara $(F)$ Spiranthes sinensis in the study area

\section{Climatic determinants of flowering phenology}

The flowering phenology results showed that a majority of species were found in flowering phase during the month of July, followed by August, June, and September. Our results match with Vashistha et al. (2009) and Khan et al. (2018) who conveyed that majority of plant species pass through their flowering phase during July and August in the Western Himalayan regions of India and Muzaffarabad, AJ\&K, Pakistan respectively. The results of this study are positively associated with the temporal climatic variations (especially temperature and monsoon rainfall) of the study area. CCA (simple term effects testing) results depicted the significant importance of four predictors including minimum temperature, wind speed, precipitation, and soil moisture ( $25 \mathrm{~cm}$ below the soil surface), whereas conditional (unique) term effects testing suggested the order of importance as mean minimum temperature followed by precipitation, wind speed and soil moisture. Many workers detected the importance and significance of temperature to the plant phenological responses (Dewald and Steiner, 1986; Badeck et al., 2004; Peñuelas et al., 2004; Ahas and Aasa, 2006; Estrella and Menzel, 2006) particularly in high altitude areas. Similarly, Khan et al. (2018) concluded that variations in the minimum temperature are more important than the maximum temperature in driving the flowering phenological variations. Precipitation was the second important determinant of the flowering 
phenological response in the study area, and Pearson (2019) reported the similar effect of precipitation on both spring and fall-flowering events from Southeast USA. Wind plays an important role in the dispersal of winged seeds over long distance (Heydel et al., 2015), and was also observed as a central factors. Our findings are alike to Khan et al. (2018) in this regard. The majority of plant species flowers in summer (July, August and June) season, so it is predicted that the months of May and June provide the essential prerequisite photo-thermic stimulus. The highest flowering phenological response of plant species from July to August can also be correlated with maximum precipitation in these months (monsoon season) resulting in higher soil moisture which in turn might resulted in required resource mobilization in the soil of the study area. A few plant species were also found in flowering stage in December to February (in winters) months depicting their unique evolutionary capabilities.

This study found that western Himalayan forests are richly diverse, and lead by Poaceae, Compositae, and Lamiaceae members. Similalrly, there is dominancy of therophytic life form and microphyllous leaf size characteristics of the vascular plant species in the study area. July and August months or monsoon season was detected as the most suitable time for plant species to pass their flowering phase, and SFR was found strongly correlated with the current climate of the study area. Intiation of flowering response was bimodal, first peak is detected in the month of April and second one in June. There were four significant groups of months/seasons linked to SFR, and monsoon season is the leading one. Mean minimum temperature, precipitation, wind speed and soil moisture in order were detected as leading drivers of flowering phenological response of the recorded plant species in the study area.

\section{Conclusions and Recommendations}

The study area (Dhirkot, AJ\&K Pakistan) harbors high plant species richness characteristics of the floristically rich and highly diverse western Himalaya of Pakistan. The dominancy of therophytic and microphyll classes suggested that the study area is under heavy anthropogenic pressure and harbors unique climatic conditions. Minimum temperature, precipitation, wind speed and soil moisture (in order) were the most important climatic determinants of flowering phenology of the recorded plant species. Based on these findings we further predict that any change especially in temperature and precipitation in the area will change flowering phenological response which might prove detrimental. The resultant negative impact on many extremely rare, endangered and endemic flora including Cedrus deodara, Taxus wallichiana, Notholirion thomsonianum, Epipactis helleborine, Aristolochia punjabensis, Jurinea dolomiaea, Swertia chirayita, Mimosa himalayana, Paeonia emodi and Skimmia laureola might result in biodiversity loss. The study area needs effective management and conservation plans for sustainable development, and future studies that focus on determination of ecological niche variations of valuable plant species under predicted climate change scenarios are required. The population of invasive alien plant species like Ailanthus altissima, Broussonetia papyrifera, Erigeron bonariensis, Lantana camara, and Parthenium hysterophorus needed to be continuously monitored in the study area. 
Acknowledgments. The authors thankfully acknowledge the local residents of the study area for sharing common names of the plant species. Authors are also thankful to the members of the herbarium of PMASArid Agriculture University, Rawalpindi, Pakistan for giving direct access to plant specimens for comparison and identification.

Author contributions. NK was involved in field data collection, and preparation of the preliminary draft; AMK developed study design, and did multivariate data analyses, results interpretation, revision and formating, NZ was involved in methodology, ZS did literature search, RWB did language editing and corrections, and RQ conceived the idea and overall supervised all the research activities.

Competing interests and funding. The author of this study have no competing interests, and this study was not financially supported by any funding agency/organization/institute etc.

\section{REFERENCES}

[1] Ahas, R., Aasa, A. (2006): The effects of climate change on the phenology of selected Estonian plant, bird and fish populations. - Int. J. Biometeorol. 51: 17-26.

[2] Ajaib, M., Khan, Z., Muhammad, S., Mahmood, R. (2008): Biological spectra of Saney Baney hills district Kotli Azad Jammu and Kashmir. - Philippine J. Sci. 60: 53-58.

[3] Ali, S. I., Nasir, Y. J. (1989-1991): Flora of Pakistan (Fascicle series). - Department of Botany, University of Karachi, Pakistan.

[4] Ali, S. I., Qaiser, M. (1993-1995 \& 2000-2014): Flora of Pakistan (Fascicle series). Department of Botany, University of Karachi, Pakistan.

[5] Amjad, M. S. (2012): Life form and leaf size spectra of vegetation in Kotli hills, Azad Jammu and Kashmir (Pakistan). - Greener J. Agri. Sci. 2: 345-350.

[6] Anynomous. (2017): City Population. - URL: <http://www.citypopulation.de/AzadKashmir.html> access on 06 May 2020.

[7] Attenborough, D. (1984): The living planet. - British Broadcasting Corporation, 320p.

[8] Badeck, F. W., Bondeau, A., Böttcher, K., Doktor, D., Lucht, W., Schaber, J., Sitch, S. (2004): Responses of spring phenology to climate change. - New phytologist 162: 295309.

[9] Batalha, M. A., Martins, F. R. (2002): Life-form spectra of Brazilian cerrado sites. - Flora 197: 452-460.

[10] Bertin, R. I. (2008): Plant phenology and distribution in relation to recent climate change. - J. Torrey. Bot. Soc. 135: 126-146.

[11] Both, C., Bouwhuis, S., Lessells, C. M., Visser, M. E. (2006): Climate change and population declines in a long-distance migratory bird. - Nature 441: 81-83.

[12] Cain, S. A., Castro, G. M. D. (1959): Manual of vegetation analysis. - Harpers and Brothers publishers, New York, pp. 225-325.

[13] Calinger, K. M., Queenborough, S., Curtis, P. S. (2013): Herbarium specimens reveal the footprint of climate change on flowering trends across North-central North America. Ecol. Lett. 16: 1037-1044.

[14] Chambers, L. E., Altwegg, R., Barbraud, C., Barnard, P., Beaumont, L. J., Crawford, R. J., Durant, J. M., Hughes, L., Keatley, M. R., Low, M., Morellato, P. C. (2013): Phenological changes in the southern hemisphere. - PloS One 18(10): e75514. https://doi.org/10.1371/journal.pone.0075514.

[15] Chaudhary, P., Rai, S., Wangdi, S., Mao, A., Rehman, N., Chettri, S., Bawa, K. S. (2011): Consistency of local perceptions of climate change in the Kangchenjunga Himalaya landscape. - Curr. Sci. 101: 504-513.

[16] Cleland, E. E., Allen, J. M., Crimmins, T. M., Dunne, J. A., Pau, S., Travers, S. E., Zavaleta, E. S., Wolkovich, E. M. (2012): Phenological tracking enables positive species responses to climate change. - Ecology 93: 1765-71. https://doi.org/10.1890/11-1912.1.

[17] Dewald, L. E., Steiner, K. C. (1986): Phenology, height increment and cold tolerance of 
Alnus glutinosa population in a common environment. - Silvae Genet. 35: 205-211.

[18] Estrella, N., Menzel, A. (2006): Responses of leaf coloring in four deciduous tree species to climate and weather in Germany. - Clim. Res. 32: 253-267.

[19] Faiz, A. H., Ghufarn, M. S., Mian, A., Akhtar, T. (2014): Floral diversity of Tolipir National Park, Azad Jammu and Kashmir, Pakistan. - Biologia (Pakistan) 60: 43-55.

[20] Fenner, M. (1998): The phenology of growth and reproduction in plants. - Perspectives in Plant Ecology, Evolution and Systematics 1: 78-91.

[21] Forrest, J. R. K. (2015): Plant-pollinator interactions and phonological change: what can we learn about climate impacts from experiments and observations? - Oikos 124: 4-13.

[22] Ge, Q., Wang, H., Rutishauser, T., Dai, J. (2015): Phenological response to climate change in China: A meta-analysis. - Glob. Chang. Biol. 21: 265-274. https://doi.org/10.1111/gcb.12648.

[23] Gill, A. L., Gallinat, A. S., Sanders-DeMott, R., Rigden, A. J., Short Gianotti, D. J., Mantooth, J. A., Templer, P. H. (2015): Changes in autumn senescence in northern hemisphere deciduous trees: a meta-analysis of autumn phenology studies. - Annals of botany 116: 875-88. https://doi.org/10.1093/aob/mcv055.

[24] Heydel, F., Cunze, S., Bernhardt-Römermann, M., Tackenberg, O. (2015): Seasonal synchronization of seed release phenology promotes long-distance seed dispersal by wind for tree species with medium wind dispersal potential. - J. Veg. Sci. 26: 1090-1101.

[25] Holway, J. G., Ward, R. T. (1965): Phenology of alpine plants in Northern Colorado. Ecology 46: 73.

[26] Ibrahim, M., Khan, M. N., Sajjad, A., Razaq, A., Zaman, A., Iqbal, M., Jan, F. (2019): Floristic composition and species diversity of plant resources of rural area "Takht Bhai" district Mardan, Khyber Pakhtunkhwa, Pakistan. - Med. Aromat. Plants (Los Angeles) 8: 338. http://doi.org/10.35248/2167-0412.19.8.338.

[27] Ilyas, M., Qureshi, R., Shinwari, Z. K., Arshad, M., Mirza, S. N., Haq, Z. U. (2013): Some ethnobotanical aspects of the plants of Qalagai hills, Kabal valley, Swat Pakistan. - Int. J. Agric. Biol. 15: 801-810.

[28] IPCC. (2007): International panel on climate change: The physical science basis-summary for policymakers. $-10^{\text {th }}$ Session of Working Group I of the IPCC, Paris.

[29] Ishaq, M., Alam, Z., Rahim, F. (2019): Floristic list and their ecological characteristics, of plants at village Derikot Selai Pattay district Malakand Khyber Pakhtunkhwa Pakistan. University of Chitral Journal of Botany 1: 93-105.

[30] Khan, R. N. (2002): Distribution and habitat preference of small mammals in Dhirkot, AJK. - Masters Thesis, University of AJ\&K, Muzaffarabad, Pakistan.

[31] Khan, M., Hussain, F., Musharaf, S., Imdadullah (2011): Floristic composition, life form and leaf size spectra of the coal mine area vegetation of Darra Adam Khel, Khyber Pakhtonkhwa, Pakistan. - J. Biodiv. Environ. Sci. 1: 1-6.

[32] Khan, M. (2013): Dimension and composition of plant life in tehsil Takht-e-Nasrati, district Karak, Khyber Pakhtunkhawa, Pakistan. - PhD Thesis, University of Peshawar, Peshawar, Khyber Pakhtunkhawa, Pakistan.

[33] Khan, M., Hussain, F., Musharaf, S. (2014): Floristic composition and ecological characteristics of Shahbaz Garhi, District Mardan, Pakistan. - Glob. J. Sci. Front. Res. 14: 7-17.

[34] Khan, A. M., Qureshi, R., Qaseem, M. F., Munir, M., Ilyas, M., Saqib, Z. (2015): Floristic checklist of district Kotli, Azad Jammu \& Kashmir. - Pak. J. Bot. 47: 1957-1968.

[35] Khan, A. M., Qureshi, R., Qaseem, M. F., Ahmad, W., Saqib, Z., Habib, T. (2016): Status of basic taxonomic skills in botanical articles related to Azad Jammu and Kashmir, Pakistan: A review. - J. Bioreso. Manag. 3: 22-54.

[36] Khan, A., Khan, N., Ali, K., Rahman, I. U. (2017): An assessment of the floristic diversity, life-forms and biological spectrum of vegetation in Swat Ranizai, district Malakand, Khyber Pakhtunkhwa, Pakistan. - Sci. Technol. Dev. 36: 61-78.

[37] Khan, A. M., Qureshi, R., Arshad, M., Mirza, S. N. (2018): Climatic and flowering 
phenological relationships of western Himalayan flora of Muzaffarabad district, Azad Jammu and Kashmir Pakistan, Pak. - J. Bot. 50: 1093-1112.

[38] Khan, A. M., Qureshi, R., Saqib, Z., Munir, M., Shaheen, H., Habib, T., Dar, M. E. U. I., Fatimah, H., Afza, R., Hussain, M. A., (2019a): A first ever detailed ecological exploration of the western Himalayan forests of Sudhan Gali and Ganga summit, Azad Jammu and Kashmir, Pakistan. - Appl. Ecol. Env. Res. 17: 15477-15505. http://dx.doi.org/10.15666/aeer/1706_1547715505.

[39] Khan, A. M., Qureshi, R., Saqib, Z. (2019b): Multivariate analyses of the vegetation of the western Himalayan forests of Muzaffarabad district, Azad Jammu and Kashmir, Pakistan. - Ecol. Indic. 104: 723-736. https://doi.org/10.1016/j.ecolind.2019.05.048.

[40] Khan, T. Y., Badshah, L., Ullah, S., Ali, A. (2019c): Floristic evaluation and ecological attributes of plants resources of Mandan, district Bannu, Pakistan. - Int. J. Bot. St. 4: 185190.

[41] Kharouba, H. M., Vellend, M. (2015): Flowering time of butterfly nectar food plants is more sensitive to temperature than the timing of butterfly adult flight. - J. Anim. Ecol. 84: 1311-1321.

[42] Lawrence, W. R. (1895): The valley of Kashmir. - Chinar Publishing House, Srinagar.

[43] Malik, Z. H. (1986): Phytosociological studies on the vegetation of Kotli Hills, Azad Jammu and Kashmir. - M. Phil. Thesis, University of Peshawar, Peshawar, Pakistan.

[44] Malik, N. Z., Malik, Z. H. (2004): Present status of sub-tropical chir pine vegetation of Kotli hills, Azad Jammu and Kashmir. - J. Scientometric Res. 15: 85-90.

[45] Menzel, A., Sparks, T. H., Estrella, N., Koch, E., Aasa, A., Ahas, R., Alm-Kübler, K., Bissolli, P., Braslavská, O. G., Briede, A., Chmielewski, F. M. (2006): European phenological response to climate change matches the warming pattern. - Global Change Biology 12: 1969-76. https://doi.org/10.1111/j.1365-2486.2006.01193.

[46] Mier, N. (2007): Grape harvest records as a proxy for Swiss April to August temperature reconstructions. - Doctoral dissertation, University of Bern, Switzerland, pp. 12-25.

[47] Mooney, H. A., Billings, W. D. (1960): The annual carbohydrate cycle of alpine plants as related to growth. - Am. J. Bot. 47: 594-598.

[48] Nasir, E., Ali, S. I. (1970-1989): Flora of Pakistan (Fascicle series). - Department of Botany, University of Karachi, Pakistan.

[49] Nazir, A., Malik, R. N., Ajaib, M. (2012): Phytosociological studies of the vegetation of Sarsawa Hills District Kotli, Azad Jammu and Kashmir. - Biologia (Pakistan) 58: 123-133.

[50] Nazir, A., Malik, R. N., Shaheen, H. (2014): Floristic composition, life form and leaf spectra of plant communities recorded at Sarsawa hills district Kotli, Azad Kashmir. - Afr. J. Soil Sci. 2: 077-078.

[51] Neil, K., Wu, J. (2006): Effects of urbanization on plant flowering phenology: A review. Urban Ecosyst. 9: 243-257.

[52] Parmesan, C., Yohe, G. (2003): A globally coherent fingerprint of climate change impacts across natural systems. - Nature 421: 37-42. https://doi.org/10.1038/nature01286.

[53] Parmesan, C. (2006): Ecological and evolutionary responses to recent climate change. Annu. Rev. Ecol. Evol. Syst. 37: 637-669.

[54] Patel, H., Jain, B. K., Dabgar, Y. B. (2010): Life form and phyto climate of Sebhargog region, North Gujarat, India. - Plant Arch. 10: 965-966.

[55] Pearson, K. D. (2019): Spring- and fall-flowering species show diverging phenological responses to climate in the Southeast USA. - Int. J. Biometeorol. 63: 481-49.

[56] Peñuelas, J., Filella, I., Zhang, X., Llorens, L., Ogaya, R., Lloret, F., Comas, P., Estiarte, M., Terradas, J. (2004): Complex spatiotemporal phenological shifts as a response to rainfall changes. - New Phytologist 161: 837-46.

[57] R Core Team (2015): R: A language and environment for statistical computing. - R Foundation for Statistical Computing, Vienna, Austria. URL: http://www.R-project.org/.

[58] Rathcke, B., Lacey, E. P. (1985): Phenological patterns of terrestrial plants. - Ann. Rev. Ecol. System. 16: 179-214. 
[59] Raunkiaer, C. (1934): The life form of plants and statistical plant geography. - The Clarendon Press, Oxford, 632p.

[60] Rosenzweig, C., Casassa, G., Karoly, D. J., Imeson, A., Liu, C., Menzel, A., Rawlins, S., Root, T. L., Seguin, B., Tryjanowski, P., Parry, M. L. (2007): Assessment of observed changes and responses in natural and managed systems. - In: Climate change 2007: Impacts, adaptation and vulnerability. Contribution of Working Group II to the Fourth Assessment Report of the Intergovernmental Panel on Climate Change, Cambridge University Press, pp. 79-131.

[61] Schwartz, M. D., Ault, T. R., Betancourt, J. L. (2013): Spring onset variations and trends in the continental United States: Past and regional assessment using temperature-based indices. - Int. J. Climatol. 33: 2917-2922.

[62] Shaheen, H., Malik, N. M., Dar, M. E. U. I. (2015): Species composition and community structure of subtropical forest stands in western Himalayan foothills of Kashmir. - Pak. J. Bot. 47: 2151-2160.

[63] Shaheen, H., Qureshi, R. A., Shinwari, Z. K. (2011): Structural diversity, vegetation dynamics and anthropogenic impact on Lesser Himalayan subtropical forests of Bagh District, Kashmir. - Pak. J. Bot. 43: 1861-1866.

[64] Shehzad, K. R., Malik, Z. H., Qureshi, R. A. (1999): Phytosociological survey of Samahni valley Bhimber, Azad Kashmir. - Pak. J. For. 49: 91-98.

[65] Shimwell, D. W. (1971): The description and classification of vegetation. - Sedgwick and Jackson, London, 322p.

[66] Shrestha, U. B., Gautam, S., Bawa, K. S. (2012): Widespread climate change in the Himalayas and associated changes in local ecosystems. - Plos One 7: e36741.

[67] Tanvir, M., Murtaza, G., Ahmad, K. S., Salman, M. (2014): Floral diversity of District Bagh, Azad Jammu and Kashmir Pakistan. - Universal J. Plant Sci. 2: 1-13.

[68] Ter Braak, C. J. F., Smilauer, P. (2012): Canoco 5, Windows release (5.00), [Software for canonical community ordination]. - Microcomputer Power, Ithaca, NY, USA.

[69] TPL. (2013): The Plant List. Version 1.1. - Avaialble at <http://www.theplantlist.org/> access on 15 April 2020.

[70] Vashistha, R. K., Rawat, N., Chaturvedi, A. K., Nautiyal, B. P., Prasad, P., Nautiyal, M. C. (2009): An exploration on the phenology of different growth forms of an alpine expanse of North-West Himalaya, India. - New York Science Journal 2(6): 29-41.

[71] Vigne, G. T. (1842): Travels in Kashmir, Ladak and Iskardo (1835-1839). - Henry Colburn, London.

[72] Wang, H., Dai, J., Rutishauser, T., Gonsamo, A., Wu, C., Ge, Q. (2018): Trends and variability in temperature sensitivity of lilac flowering phenology. - J. Geophys. Res. Biogeo. 123: 807-817.

[73] Williams, T. A., Abberton, M. T. (2004): Earlier flowering between 1962 and 2002 in agricultural varieties of white clover. - Oecologia 138: 122-126.

[74] Willis, C. G., Ruhfel, B., Primack, R. B., Miller-Rushing, A. J., Davis, C. C. (2008): Phylogenetic patterns of species loss in Thoreau's woods are driven by climate change. Proceedings of the National Academy of Sciences of the United States of America 105: 17029-17033. https://doi.org/10.1073/pnas.0806446105. 


$$
-320 \text { - }
$$

\section{APPENDIX}

Supplementary Data Table 1. Floristic list of the vascular plants species of Dhirkot, district Bagh, and their various attributes

\begin{tabular}{|c|c|c|c|c|c|c|c|}
\hline Family & $\begin{array}{c}\text { Species names } \\
\text { and Voucher No. }\end{array}$ & Local name & Habit & $\begin{array}{c}\text { Life } \\
\text { forms }\end{array}$ & $\begin{array}{c}\text { Leaf } \\
\text { spectra }\end{array}$ & Phenology & Status \\
\hline \multicolumn{8}{|c|}{ Pteridophytes } \\
\hline Aspleniaceae & $\begin{array}{c}\text { Asplenium } \\
\text { dalhousiae Hook. } \\
\text { / NK98 }\end{array}$ & Alaf jarhi & $\mathrm{H}$ & G & Mep & Jun-Dec & Native $\mathrm{Ra}, \mathrm{NI}$ \\
\hline Dryopteridaceae & $\begin{array}{c}\text { Dryopteris } \\
\text { ramosa } \text { (C. Hope) } \\
\text { C. Chr. / NK99 }\end{array}$ & Kunji & $\mathrm{H}$ & G & Map & Jun-Sep & Native ${ }^{R a, N I}$ \\
\hline \multirow[t]{7}{*}{ Pteridaceae } & $\begin{array}{c}\text { Adiantum } \\
\text { capillus-veneris L. } \\
\text { / NK100 }\end{array}$ & Kakwai & $\mathrm{H}$ & G & Mip & May-Aug & Native ${ }^{R a, N I}$ \\
\hline & $\begin{array}{c}\text { Adiantum } \\
\text { raddianum } \mathrm{C} \text {. } \\
\text { Presl / NK101 }\end{array}$ & Parsoshan & $\mathrm{H}$ & G & Mep & Jun-Sep & Introduced ${ }^{\mathrm{Ra}, \mathrm{NI}}$ \\
\hline & $\begin{array}{c}\text { Adiantum } \\
\text { venustum } \mathrm{D} \text {. Don / } \\
\text { NK102 }\end{array}$ & Kakwai & $\mathrm{H}$ & G & Mip & May-Aug & Native $\mathrm{VC}, \mathrm{NI}$ \\
\hline & $\begin{array}{c}\text { Onychium } \\
\text { japonicum } \\
\text { (Thunb.) Kunze / } \\
\text { NK103 }\end{array}$ & Kunji & $\mathrm{H}$ & G & Map & Jun-Sep & Introduced ${ }^{\mathrm{Ra}, \mathrm{NI}}$ \\
\hline & $\begin{array}{c}\text { Pteris cretica L. / } \\
\text { NK104 }\end{array}$ & Nanoor & $\mathrm{H}$ & $\mathrm{Hc}$ & Map & Jun-Aug & Native ${ }^{\mathrm{Co}, \mathrm{NI}}$ \\
\hline & $\begin{array}{c}\text { Pteris vittata L. I } \\
\text { NK105 }\end{array}$ & Nanoor & $\mathrm{H}$ & G & Map & Jun-Aug & Native ${ }^{\mathrm{Co}, \mathrm{NI}}$ \\
\hline & \multicolumn{7}{|c|}{ Gymnosperms } \\
\hline \multirow[t]{3}{*}{ Pinaceae } & $\begin{array}{c}\text { Cedrus deodara } \\
\text { (Roxb.ex D. Don) } \\
\text { G.Don / NK106 }\end{array}$ & Deyaar & $\mathrm{T}$ & $\mathrm{Mp}$ & Lep & Oct-Nov & Native ${ }^{R a, N I}$ \\
\hline & $\begin{array}{l}\text { Pinus roxburghii } \\
\text { Sarg. / NK107 }\end{array}$ & Chir & $\mathrm{T}$ & $\mathrm{Mp}$ & Lep & Mar-Apr & Native VC, NI \\
\hline & $\begin{array}{c}\text { Pinus wallichiana } \\
\text { A.B.Jacks. / } \\
\text { NK108 }\end{array}$ & Beyaarh & $\mathrm{T}$ & $\mathrm{Mp}$ & Lep & Apr-Jun & Native $\mathrm{VC}, \mathrm{NI}$ \\
\hline \multirow[t]{2}{*}{ Taxaceae } & $\begin{array}{c}\text { Taxus wallichiana } \\
\text { Zucc. / NK109 }\end{array}$ & Tooni & $\mathrm{T}$ & Ms & Lep & Feb-Mar & Native ${ }^{R a, N I}$ \\
\hline & & \multicolumn{6}{|c|}{ Monocotyledons } \\
\hline \multirow[t]{2}{*}{ Araceae } & $\begin{array}{c}\text { Arisaema } \\
\text { jacquemontii } \\
\text { Blume / NK110 }\end{array}$ & $\begin{array}{l}\text { Sap booti, } \\
\text { Cobra plant }\end{array}$ & $\mathrm{H}$ & G & Mep & Jun-Jul & Native ${ }^{R a, N I}$ \\
\hline & $\begin{array}{c}\text { Sauromatum } \\
\text { venosum (Dryand. } \\
\text { ex Aiton) Kunth / } \\
\text { NK111. }\end{array}$ & Adbees & $\mathrm{H}$ & G & Mep & Apr-May & Native ${ }^{\mathrm{Co}, \mathrm{NI}}$ \\
\hline
\end{tabular}




\begin{tabular}{|c|c|c|c|c|c|c|c|}
\hline Family & $\begin{array}{l}\text { Species names } \\
\text { and Voucher No. }\end{array}$ & Local name & Habit & $\begin{array}{c}\text { Life } \\
\text { forms }\end{array}$ & $\begin{array}{c}\text { Leaf } \\
\text { spectra }\end{array}$ & Phenology & Status \\
\hline Commelinaceae & $\begin{array}{c}\text { Commelina } \\
\text { benghalensis L. / } \\
\text { NK112 }\end{array}$ & $\begin{array}{l}\text { Kanteri, } \\
\text { Chura }\end{array}$ & $\mathrm{H}$ & Th & Mip & Jun-Sep & Native ${ }^{\mathrm{Co}, \mathrm{NI}}$ \\
\hline \multirow[t]{11}{*}{ Cyperaceae } & $\begin{array}{l}\text { Carex brunnea } \\
\text { Thunb. / NK113 }\end{array}$ & Kangri malla & $\mathrm{H}$ & Th & Nap & Jul-Aug & Native Ra, NI \\
\hline & $\begin{array}{c}\text { Cyperus arenarius } \\
\text { Retz. / NK114 }\end{array}$ & Unavailable & $\mathrm{H}$ & G & Nap & Mar-May & Native ${ }^{\mathrm{Co}, \mathrm{NI}}$ \\
\hline & $\begin{array}{c}\text { Cyperus } \\
\text { compressus L. / } \\
\text { NK115 } \\
\end{array}$ & Elegant sedge & $\mathrm{H}$ & Th & Lep & Jul-Oct & Native ${ }^{\mathrm{C} 0, \mathrm{NI}}$ \\
\hline & $\begin{array}{c}\text { Cyperus difformis } \\
\text { L. / NK116 }\end{array}$ & Daila & $\mathrm{H}$ & $\mathrm{Hc}$ & Nap & Jul-Oct & Native ${ }^{\mathrm{Co}, \mathrm{NI}}$ \\
\hline & $\begin{array}{c}\text { Cyperus iria L. / } \\
\text { NK117 }\end{array}$ & Bhoian & $\mathrm{H}$ & Th & Mip & May-Oct & Native $^{\mathrm{VR}, \mathrm{NI}}$ \\
\hline & $\begin{array}{l}\text { Cyperus niveus } \\
\text { Retz. / NK118 }\end{array}$ & Snow white & $\mathrm{H}$ & $\mathrm{Hc}$ & Nap & Apr-Jun & Native ${ }^{R a, N I}$ \\
\hline & $\begin{array}{l}\text { Cyperus rotundus } \\
\text { L. / NK119 }\end{array}$ & Nagarmotha & $\mathrm{H}$ & G & Nap & Apr-Oct & Native ${ }^{\mathrm{Co}, \mathrm{In}}$ \\
\hline & $\begin{array}{l}\text { Cyperus serotinus } \\
\text { Rottb. / NK120 }\end{array}$ & Unavailable & $\mathrm{H}$ & Th & Nap & Jul-Sep & Native Ra, NI \\
\hline & $\begin{array}{c}\text { Eriophorum } \\
\text { comosum (Wall.) } \\
\text { Nees / NK121 }\end{array}$ & Babya & $\mathrm{H}$ & $\mathrm{Hc}$ & Mip & Jul-Sep & Native ${ }^{\mathrm{VC}, \mathrm{NI}}$ \\
\hline & $\begin{array}{c}\text { Fimbristylis } \\
\text { bisumbellata } \\
\text { (Forssk.) Bubani / } \\
\text { NK122 }\end{array}$ & Choti bhuini & $\mathrm{H}$ & Th & Nap & Jul-Oct & Native ${ }^{\mathrm{Co}, \mathrm{NI}}$ \\
\hline & $\begin{array}{c}\text { Fimbristylis } \\
\text { dichotoma (L.) } \\
\text { Vahl / NK123 } \\
\end{array}$ & Choti bhuini & $\mathrm{H}$ & G & Nap & Aug-Oct & Native ${ }^{\mathrm{Co}, \mathrm{NI}}$ \\
\hline \multirow[t]{2}{*}{ Liliaceae } & $\begin{array}{c}\text { Notholirion } \\
\text { thomsonianum } \\
\text { (Royle) Stapf / } \\
\text { NK124 }\end{array}$ & Hazara lily & $\mathrm{H}$ & G & Mip & Apr-May & Native $^{\mathrm{Ra}, \mathrm{NI}}$ \\
\hline & $\begin{array}{l}\text { Tulipa clusiana } \\
\text { DC. / NK125 }\end{array}$ & Kakarh mula & $\mathrm{H}$ & G & Mip & Mar-May & Native $^{\mathrm{Co}, \mathrm{NI}}$ \\
\hline \multirow[t]{2}{*}{ Orchidaceae } & $\begin{array}{c}\text { Epipactis } \\
\text { helleborine (L.) } \\
\text { Crantz / NK126 }\end{array}$ & Koka maki & $\mathrm{H}$ & G & Mip & Jun-Aug & Native $^{\mathrm{Ra}, \mathrm{NI}}$ \\
\hline & $\begin{array}{c}\text { Spiranthes } \\
\text { sinensis (Pers.) } \\
\text { Ames / NK127 }\end{array}$ & Chitti batti & $\mathrm{H}$ & G & Nap & May-Sep & Introduced ${ }^{\mathrm{VR}, \mathrm{NI}}$ \\
\hline \multirow[t]{4}{*}{ Poaceae } & $\begin{array}{c}\text { Agrostis canina } \mathrm{L} . \\
\text { / NK128 }\end{array}$ & Kaah & $\mathrm{H}$ & Th & Nap & Jul-Aug & Native $^{\mathrm{VC}, \mathrm{NI}}$ \\
\hline & $\begin{array}{l}\text { Agrostis gigantea } \\
\text { Roth / NK129 }\end{array}$ & Kaah & $\mathrm{H}$ & $\mathrm{Hc}$ & Mip & Jun-Aug & Native ${ }^{\mathrm{VC}, \mathrm{NI}}$ \\
\hline & $\begin{array}{c}\text { Apluda mutica L. I } \\
\text { NK130 }\end{array}$ & Ghagari & $\mathrm{H}$ & $\mathrm{Hc}$ & Nap & Aug-Nov & Native ${ }^{\mathrm{Co}, \mathrm{NI}}$ \\
\hline & $\begin{array}{c}\text { Aristida funiculata } \\
\text { Trin. \& Rupr. / } \\
\text { NK131 }\end{array}$ & Lamb & $\mathrm{H}$ & Th & Mip & Jun-Sep & Native ${ }^{\mathrm{Co}, \mathrm{NI}}$ \\
\hline
\end{tabular}




\begin{tabular}{|c|c|c|c|c|c|c|c|}
\hline Family & $\begin{array}{c}\text { Species names } \\
\text { and Voucher No. }\end{array}$ & Local name & Habit & $\begin{array}{l}\text { Life } \\
\text { forms }\end{array}$ & $\begin{array}{c}\text { Leaf } \\
\text { spectra }\end{array}$ & Phenology & Status \\
\hline & $\begin{array}{c}\text { Arundinella } \\
\text { nepalensis Trin. / } \\
\text { NK132 }\end{array}$ & Garali & $\mathrm{H}$ & G & Mip & Sep-Nov & Native ${ }^{\mathrm{VC}, \mathrm{NI}}$ \\
\hline & $\begin{array}{c}\text { Arundo donax L. I } \\
\text { NK133 }\end{array}$ & Nari & $\mathrm{H}$ & $\mathrm{Hc}$ & Map & Jun-Oct & Native ${ }^{\mathrm{Co}, \mathrm{In}}$ \\
\hline & $\begin{array}{c}\text { Avena fatua L. / } \\
\text { NK134 }\end{array}$ & Jwaan seela & $\mathrm{H}$ & Th & Nap & May-Aug & Native ${ }^{\mathrm{VC}, \mathrm{NI}}$ \\
\hline & $\begin{array}{c}\text { Brachiaria } \\
\text { ramosa }(\text { L.) Stapf } \\
\text { / NK135 }\end{array}$ & Kanderi & $\mathrm{H}$ & Th & Mip & Jul-Oct & Native ${ }^{\mathrm{Co}, \mathrm{NI}}$ \\
\hline & $\begin{array}{c}\text { Brachypodium } \\
\text { sylvaticum (Huds.) } \\
\text { P. Beauv. / } \\
\text { NK136 }\end{array}$ & Bitkaai & $\mathrm{H}$ & Th & Mip & Jun-Sep & Native ${ }^{\mathrm{VC}, \mathrm{NI}}$ \\
\hline & $\begin{array}{c}\text { Bromus } \\
\text { catharticus Vahl / } \\
\text { NK137 }\end{array}$ & Tank & $\mathrm{H}$ & $\mathrm{Hc}$ & Mip & Apr-Jun & Introduced ${ }^{\mathrm{VC}, \mathrm{NI}}$ \\
\hline & $\begin{array}{c}\text { Chrysopogon } \\
\text { gryllus (L.) Trin. / } \\
\text { NK138 }\end{array}$ & Bari kaah & $\mathrm{H}$ & $\mathrm{Hc}$ & Nap & Jun-Aug & Native ${ }^{\mathrm{VC}, \mathrm{NI}}$ \\
\hline & $\begin{array}{c}\text { Chrysopogon } \\
\text { serrulatus Trin. / } \\
\text { NK139 }\end{array}$ & Jargi kaah & $\mathrm{H}$ & $\mathrm{Hc}$ & Nap & Jun-Aug & Native $^{\mathrm{Co}, \mathrm{NI}}$ \\
\hline & $\begin{array}{c}\text { Cymbopogon } \\
\text { jwarancusa } \\
\text { (Jones) Schult. / } \\
\text { NK140 }\end{array}$ & Khawi & $\mathrm{H}$ & $\mathrm{Hc}$ & Nap & Mar-May & Native ${ }^{R a, N I}$ \\
\hline & $\begin{array}{l}\text { Cynodon dactylon } \\
\text { (L.) Pers. / NK141 }\end{array}$ & Khabbal & $\mathrm{H}$ & $\mathrm{Hc}$ & Lep & Whole year & Native ${ }^{\mathrm{VC}, \mathrm{NI}}$ \\
\hline & $\begin{array}{c}\text { Dactylis } \\
\text { glomerata L. / } \\
\text { NK142 }\end{array}$ & Samaki & $\mathrm{H}$ & $\mathrm{Hc}$ & Mip & Jul-Aug & Native ${ }^{\mathrm{Co}, \mathrm{NI}}$ \\
\hline & $\begin{array}{l}\text { Dactyloctenium } \\
\text { aegyptium (L.) } \\
\text { Willd. / NK143 }\end{array}$ & $\begin{array}{l}\text { Madhani } \\
\text { kaah }\end{array}$ & $\mathrm{H}$ & Th & Nap & Jul-Oct & Native $^{\text {Ra, NI }}$ \\
\hline & $\begin{array}{c}\text { Dichanthium } \\
\text { annulatum } \\
\text { (Forssk.) Stapf / } \\
\text { NK144 }\end{array}$ & Murgha kaah & $\mathrm{H}$ & $\mathrm{Hc}$ & Lep & Mar-Oct & Native ${ }^{\mathrm{Co}, \mathrm{NI}}$ \\
\hline & $\begin{array}{c}\text { Digitaria } \\
\text { sanguinalis }(\mathrm{L} .) \\
\text { Scop. / NK145 }\end{array}$ & $\begin{array}{c}\text { Tarakhni } \\
\text { malla }\end{array}$ & $\mathrm{H}$ & $\mathrm{Hc}$ & Mip & Jul-Sep & Native ${ }^{\mathrm{VC}, \mathrm{NI}}$ \\
\hline & $\begin{array}{c}\text { Digitaria } \\
\text { violascens Link / } \\
\text { NK146 }\end{array}$ & $\begin{array}{c}\text { Tarakhni } \\
\text { malla }\end{array}$ & $\mathrm{H}$ & $\mathrm{Hc}$ & Mip & Jul-Aug & Native ${ }^{\mathrm{VC}, \mathrm{NI}}$ \\
\hline & $\begin{array}{c}\text { Echinochloa } \\
\text { colona }(\text { L.) Link / } \\
\text { NK147 }\end{array}$ & Malla kaah & $\mathrm{H}$ & Th & Mip & May-Sep & Native ${ }^{\mathrm{Co}, \mathrm{NI}}$ \\
\hline & $\begin{array}{l}\text { Eleusine indica } \\
\text { (L.) Gaertn. / } \\
\text { NK148 }\end{array}$ & Goose grass & $\mathrm{H}$ & Th & Mip & Jun-Aug & Native ${ }^{\mathrm{Co}, \mathrm{NI}}$ \\
\hline & $\begin{array}{l}\text { Eragrostis pilosa } \\
\text { (L.) P. Beauv. / } \\
\text { NK149 }\end{array}$ & Barboori & $\mathrm{H}$ & Th & Mip & Jul-Oct & Native $\mathrm{VC}, \mathrm{NI}$ \\
\hline
\end{tabular}




\begin{tabular}{|c|c|c|c|c|c|c|c|}
\hline \multirow[t]{18}{*}{ Family } & $\begin{array}{c}\text { Species names } \\
\text { and Voucher No. }\end{array}$ & Local name & Habit & $\begin{array}{l}\text { Life } \\
\text { forms }\end{array}$ & $\begin{array}{c}\text { Leaf } \\
\text { spectra }\end{array}$ & Phenology & Status \\
\hline & $\begin{array}{c}\text { Heteropogon } \\
\text { contortus }(\mathrm{L} .) \text { P. } \\
\text { Beauv. ex Roem. } \\
\text { \& Schult. / NK150 }\end{array}$ & Sureli & $\mathrm{H}$ & $\mathrm{Hc}$ & Mip & Jun-Oct & Native ${ }^{\mathrm{VC}, \mathrm{NI}}$ \\
\hline & $\begin{array}{c}\text { Leptochloa } \\
\text { panicea (Retz.) } \\
\text { Ohwi / NK151 }\end{array}$ & Kaah & $\mathrm{H}$ & Th & Mip & Sep-Nov & Native ${ }^{\mathrm{VC}, \mathrm{NI}}$ \\
\hline & $\begin{array}{c}\text { Oplismenus } \\
\text { compositus }(\mathrm{L} .) \\
\text { P.Beauv. / NK152 }\end{array}$ & Malla & $\mathrm{H}$ & $\mathrm{Hc}$ & Mip & Aug-Sep & Native ${ }^{\mathrm{Co}, \mathrm{NI}}$ \\
\hline & $\begin{array}{c}\text { Oplismenus } \\
\text { undulatifolius } \\
\text { (Ard.) Roem. \& } \\
\text { Schult. / NK153 }\end{array}$ & Malla & $\mathrm{H}$ & $\mathrm{Hc}$ & Mip & Aug-Sep & Native ${ }^{\mathrm{VC}, \mathrm{NI}}$ \\
\hline & $\begin{array}{c}\text { Paspalidium } \\
\text { flavidum (Retz.) } \\
\text { A.Camus / NK154 }\end{array}$ & Kangna & $\mathrm{H}$ & $\mathrm{Hc}$ & Mip & Jul-Oct & Native ${ }^{\mathrm{Co}, \mathrm{NI}}$ \\
\hline & $\begin{array}{c}\text { Paspalum } \\
\text { distichum L. / } \\
\text { NK155 }\end{array}$ & Daila & $\mathrm{H}$ & $\mathrm{Hc}$ & Nap & Apr-May & Introduced ${ }^{\mathrm{Ra}, \mathrm{NI}}$ \\
\hline & $\begin{array}{c}\text { Pennisetum } \\
\text { flaccidum Griseb. } \\
\text { / NK156 }\end{array}$ & $\begin{array}{l}\text { Manehra } \\
\text { kaah }\end{array}$ & $\mathrm{H}$ & $\mathrm{Hc}$ & Mip & Jun-Oct & Native ${ }^{\mathrm{VC}, \mathrm{NI}}$ \\
\hline & $\begin{array}{c}\text { Pennisetum } \\
\text { glaucum (L.) R. } \\
\text { Br. / NK157 }\end{array}$ & Phulai & $\mathrm{H}$ & $\mathrm{Hc}$ & Mip & Jun-Aug & Introduced ${ }^{\mathrm{Co}, \mathrm{NI}}$ \\
\hline & $\begin{array}{c}\text { Pennisetum } \\
\text { orientale Rich. / } \\
\text { NK158 }\end{array}$ & Phulai & $\mathrm{H}$ & $\mathrm{Hc}$ & Mip & Apr-Oct & Native ${ }^{\mathrm{Co}, \mathrm{NI}}$ \\
\hline & $\begin{array}{l}\text { Phalaris minor } \\
\text { Retz. / NK159 }\end{array}$ & Dumbi sitti & $\mathrm{H}$ & Th & Mip & Mar-May & Native ${ }^{\mathrm{Co}, \mathrm{NI}}$ \\
\hline & $\begin{array}{c}\text { Piptatherum } \\
\text { munroi (Stapf ex } \\
\text { Hook. f.) Mez / } \\
\text { NK160 }\end{array}$ & Smilo grass & $\mathrm{H}$ & $\mathrm{Hc}$ & Mip & Jun-Sep & Native ${ }^{\mathrm{VC}, \mathrm{NI}}$ \\
\hline & $\begin{array}{c}\text { Роа аппиа L. / } \\
\text { NK161 }\end{array}$ & Kaah & $\mathrm{H}$ & Th & Mip & Mar-Sep & Native $^{\mathrm{VC}, \mathrm{NI}}$ \\
\hline & $\begin{array}{l}\text { Polypogon viridis } \\
\text { (Gouan) Breistr. / } \\
\text { NK162 }\end{array}$ & Pochar & $\mathrm{H}$ & $\mathrm{Hc}$ & Mep & May-Aug & Native $\mathrm{VC}, \mathrm{NI}$ \\
\hline & $\begin{array}{c}\text { Saccharum } \\
\text { spontaneum Linn. } \\
\text { / NK163 }\end{array}$ & Kamath & $\mathrm{H}$ & $\mathrm{Hc}$ & Mip & Jul-Sep & Native $\mathrm{VC}, \mathrm{NI}$ \\
\hline & $\begin{array}{l}\text { Setaria pumila } \\
\text { (Poir.) Roem. \& } \\
\text { Schult. / NK164 }\end{array}$ & Kangri mallo & $\mathrm{H}$ & Th & Mip & Jun-Oct & Native $\mathrm{VC}, \mathrm{In}$ \\
\hline & $\begin{array}{c}\text { Setaria viridis (L.) } \\
\text { P. Beauv. / } \\
\text { NK165 }\end{array}$ & Kangrel & $\mathrm{H}$ & Th & Mip & Jun-Sep & Native ${ }^{\mathrm{VC}, \mathrm{NI}}$ \\
\hline & $\begin{array}{c}\text { Sorghum } \\
\text { halepense (L.) } \\
\text { Pers. / NK166 }\end{array}$ & Barru kaah & $\mathrm{H}$ & G & Mip & May-Oct & Native ${ }^{\mathrm{VC}}$, In \\
\hline
\end{tabular}




$$
-324 \text { - }
$$

\begin{tabular}{ccccccccc}
\hline Family & $\begin{array}{c}\text { Species names } \\
\text { and Voucher No. }\end{array}$ & Local name & Habit & $\begin{array}{c}\text { Life } \\
\text { forms }\end{array}$ & $\begin{array}{c}\text { Leaf } \\
\text { spectra }\end{array}$ & Phenology & Status \\
\hline $\begin{array}{c}\text { Themeda anathera } \\
\text { (Nees ex Steud.) } \\
\text { Hack. / NK167 }\end{array}$ & Samaki & H & Hc & Nap & Jun-Oct & Native ${ }^{\text {VC, NI }}$ \\
\hline $\begin{array}{c}\text { Tragus } \\
\text { berteronianus } \\
\text { Schult. / NK168 }\end{array}$ & Unavailable & H & Th & Nap & Nov-Apr & Native ${ }^{\text {Ra, NI }}$ \\
\hline
\end{tabular}

\section{Dicotyledons}

\begin{tabular}{|c|c|c|c|c|c|c|c|}
\hline Acanthaceae & $\begin{array}{c}\text { Dicliptera } \\
\text { bupleuroides Nees } \\
\text { / NK169 }\end{array}$ & Somni & $\mathrm{H}$ & $\mathrm{Hc}$ & Nap & Jun-Oct & Native ${ }^{\mathrm{VC}, \mathrm{NI}}$ \\
\hline & $\begin{array}{c}\text { Dicliptera } \\
\text { paniculata } \\
\text { (Forssk.) I. } \\
\text { Darbysh. / NK170 }\end{array}$ & Toot tallo & $\mathrm{H}$ & Th & Mip & Dec-Feb & Native ${ }^{V C}, \mathrm{NI}$ \\
\hline & $\begin{array}{c}\text { Justicia adhatoda } \\
\text { L. / NK171 }\end{array}$ & Bekarh & S & $\mathrm{Np}$ & Мep & Jul-Oct & Native ${ }^{\mathrm{VC}, \mathrm{NI}}$ \\
\hline & $\begin{array}{c}\text { Strobilanthes } \\
\text { urticifolia Wall. } \\
\text { ex Kuntze / } \\
\text { NK172 }\end{array}$ & Bekarhi & $\mathrm{H}$ & $\mathrm{Ch}$ & Мep & Jun-Oct & Native $\mathrm{VC}, \mathrm{In}$ \\
\hline Adoxaceae & $\begin{array}{c}\text { Viburnum } \\
\text { grandiflorum } \\
\text { Wall. ex DC / } \\
\text { NK173 }\end{array}$ & Guch & $S$ & $\mathrm{~Np}$ & Мep & Nov-Jun & Native ${ }^{V C}, \mathrm{NI}$ \\
\hline \multirow[t]{8}{*}{ Amaranthaceae } & $\begin{array}{c}\text { Achyranthes } \\
\text { aspera L. / NK174 }\end{array}$ & Puth kanda & $\mathrm{H}$ & $\mathrm{Ch}$ & Mip & Jul-Oct & Native ${ }^{\mathrm{VC}, \mathrm{In}}$ \\
\hline & $\begin{array}{l}\text { Alternanthera } \\
\text { pungens Kunth / } \\
\text { NK175 }\end{array}$ & Bakharha & $\mathrm{H}$ & Th & Mip & Aug-Oct & Introduced ${ }^{\mathrm{Co}, \mathrm{NI}}$ \\
\hline & $\begin{array}{l}\text { Amaranthus } \\
\text { caudatus L. / } \\
\text { NK176 }\end{array}$ & Baghi ganehr & $\mathrm{H}$ & Th & Mep & May-Aug & Introduced ${ }^{\mathrm{Co}, \mathrm{NI}}$ \\
\hline & $\begin{array}{l}\text { Amaranthus } \\
\text { hybridus L. / } \\
\text { NK177 }\end{array}$ & Surkh ganehr & $\mathrm{H}$ & Th & Mip & Jul-Oct & Introduced $\mathrm{VC}$, In \\
\hline & $\begin{array}{c}\text { Amaranthus } \\
\text { retroflexus L. / } \\
\text { NK178 }\end{array}$ & Ganehr & $\mathrm{H}$ & Th & Mip & Jul-Sep & Introduced ${ }^{\mathrm{Co}, \mathrm{NI}}$ \\
\hline & $\begin{array}{c}\text { Amaranthus } \\
\text { viridis L. / NK179 }\end{array}$ & Ganehr & $\mathrm{H}$ & Th & Mip & Mar-Oct & Introduced $\mathrm{VC}$, In \\
\hline & $\begin{array}{l}\text { Chenopodium } \\
\text { album L. / NK180 }\end{array}$ & Bathwa & $\mathrm{H}$ & Th & Mip & May-Oct & Native VC, In \\
\hline & $\begin{array}{l}\text { Digera muricata } \\
\text { (L.) Mart. / } \\
\text { NK181 }\end{array}$ & Tandla & $\mathrm{H}$ & Th & Mip & Aug-Sep & Native ${ }^{\mathrm{Co}, \mathrm{NI}}$ \\
\hline Anacardiaceae & $\begin{array}{c}\text { Cotinus coggygria } \\
\text { Scop. / NK182 }\end{array}$ & Pann & S & $\mathrm{Np}$ & Mip & Apr-May & Native ${ }^{\mathrm{Co}, \mathrm{NI}}$ \\
\hline Apiaceae & $\begin{array}{l}\text { Bupleurum } \\
\text { falcatum L. / } \\
\text { NK183 }\end{array}$ & Patti & $\mathrm{H}$ & $\mathrm{Hc}$ & Nap & Jun-Oct & Native ${ }^{\mathrm{Co}, \mathrm{NI}}$ \\
\hline
\end{tabular}




\begin{tabular}{|c|c|c|c|c|c|c|c|}
\hline Family & $\begin{array}{c}\text { Species names } \\
\text { and Voucher No. }\end{array}$ & Local name & Habit & $\begin{array}{c}\text { Life } \\
\text { forms }\end{array}$ & $\begin{array}{c}\text { Leaf } \\
\text { spectra }\end{array}$ & Phenology & Status \\
\hline & $\begin{array}{c}\text { Conium } \\
\text { maculatum L. / } \\
\text { NK184 }\end{array}$ & Morkach & $\mathrm{H}$ & $\mathrm{Hc}$ & Mip & Jun-Aug & Native ${ }^{\mathrm{Co}, \mathrm{NI}}$ \\
\hline & $\begin{array}{l}\text { Foeniculum } \\
\text { vulgare Mill. / } \\
\text { NK185 }\end{array}$ & Saunf & $\mathrm{H}$ & $\mathrm{Hc}$ & Nap & Aug-Oct & Native VR, NI \\
\hline & $\begin{array}{c}\text { Pimpinella } \\
\text { stewartii Nasir / } \\
\text { NK186 }\end{array}$ & Unavailable & $\mathrm{H}$ & $\mathrm{Ch}$ & Nap & Jun-Aug & Native ${ }^{\mathrm{Co}, \mathrm{NI}}$ \\
\hline Apocynaceae & $\begin{array}{l}\text { Nerium oleander } \\
\text { L. / NK187 }\end{array}$ & Kaneera & $S$ & $\mathrm{~Np}$ & Mip & Apr-Oct & Native ${ }^{\mathrm{VC}, \text { In }}$ \\
\hline Araliaceae & $\begin{array}{l}\text { Hedera helix L. I } \\
\text { NK188 }\end{array}$ & $\begin{array}{l}\text { Batkal, } \\
\text { Harhbamal }\end{array}$ & $\mathrm{C}$ & $\mathrm{L}$ & Mip & Oct-Apr & Native ${ }^{\mathrm{Co}, \mathrm{NI}}$ \\
\hline Aristolochiaceae & $\begin{array}{c}\text { Aristolochia } \\
\text { punjabensis Lace / } \\
\text { NK189 }\end{array}$ & $\begin{array}{c}\text { Kutyari, } \\
\text { kuttay booti }\end{array}$ & $S$ & $\mathrm{~Np}$ & Mip & Jun-Jul & Native Ra, NI \\
\hline Balsaminaceae & $\begin{array}{c}\text { Impatiens } \\
\text { edgeworthii Hook. } \\
\text { f. / NK224 }\end{array}$ & Bantil & $\mathrm{H}$ & Th & Mep & Jul-Sep & Native ${ }^{\mathrm{VC}, \mathrm{NI}}$ \\
\hline Berberidaceae & $\begin{array}{l}\text { Berberis lycium } \\
\text { Royle / NK225 }\end{array}$ & Sumbal & S & $\mathrm{Np}$ & Nap & Apr-Jun & Native $^{\mathrm{VC}, \mathrm{NI}}$ \\
\hline \multirow[t]{2}{*}{ Boraginaceae } & $\begin{array}{c}\text { Cynoglossum } \\
\text { lanceolatum } \\
\text { Forssk. / NK226 }\end{array}$ & Churoon & $\mathrm{H}$ & Th & Mip & Jun-Aug & Native ${ }^{\mathrm{VC}, \mathrm{NI}}$ \\
\hline & $\begin{array}{l}\text { Cynoglossum } \\
\text { wallichii Var. } \\
\text { glochidiatum } \\
\text { (Wall. ex Benth.) } \\
\text { Kazmi / NK227 }\end{array}$ & Phulari jarhi & $\mathrm{H}$ & Th & Mip & May-Aug & Native ${ }^{\mathrm{VC}, \mathrm{NI}}$ \\
\hline \multirow[t]{6}{*}{ Brassicaceae } & $\begin{array}{l}\text { Capsella bursa- } \\
\text { pastoris (L.) } \\
\text { Medik. / NK228 }\end{array}$ & Ban paincha & $\mathrm{H}$ & Th & Mip & May-Jul & Native ${ }^{\mathrm{VC}}$, In \\
\hline & $\begin{array}{c}\text { Conringia } \\
\text { orientalis (L.) } \\
\text { Dumort. / NK229 }\end{array}$ & Ban sariyaan & $\mathrm{H}$ & Th & Mip & Apr-May & Native ${ }^{\mathrm{Co}, \mathrm{NI}}$ \\
\hline & $\begin{array}{c}\text { Lepidium } \\
\text { apetalum Willd. / } \\
\text { NK230 }\end{array}$ & Duda patti & $\mathrm{H}$ & Th & Mip & Apr-Jun & Native ${ }^{\mathrm{VC}, \mathrm{NI}}$ \\
\hline & $\begin{array}{l}\text { Lepidium } \\
\text { didymum L. / } \\
\text { NK231 }\end{array}$ & Jangli hallon & $\mathrm{H}$ & Th & Mip & Mar-Jun & Introduced ${ }^{\mathrm{Ra}, \mathrm{NI}}$ \\
\hline & $\begin{array}{l}\text { Sinapis arvensis } \\
\text { L. / NK232 }\end{array}$ & Ban sariyaan & $\mathrm{H}$ & Th & Mip & Apr-Jun & Native ${ }^{\mathrm{Co}, \mathrm{NI}}$ \\
\hline & $\begin{array}{c}\text { Sisymbrium irio L. } \\
\text { / NK233 }\end{array}$ & Ban hailyan & $\mathrm{H}$ & Th & Mip & Mar-May & Native ${ }^{\mathrm{Co}, \mathrm{NI}}$ \\
\hline Buxaceae & $\begin{array}{c}\text { Sarcococca } \\
\text { saligna (D. Don) } \\
\text { Müll-Arg. / } \\
\text { NK234 }\end{array}$ & Nairi & $S$ & $\mathrm{~Np}$ & Mip & Sep-Apr & Native ${ }^{\mathrm{VC}, \mathrm{NI}}$ \\
\hline Campanulaceae & $\begin{array}{c}\text { Campanula } \\
\text { pallida Wall. / } \\
\text { NK235 }\end{array}$ & Beli flower & $\mathrm{H}$ & Th & Nap & Apr-Jul & Native Ra, NI \\
\hline
\end{tabular}




\begin{tabular}{|c|c|c|c|c|c|c|c|}
\hline Family & $\begin{array}{c}\text { Species names } \\
\text { and Voucher No. }\end{array}$ & Local name & Habit & $\begin{array}{l}\text { Life } \\
\text { forms }\end{array}$ & $\begin{array}{c}\text { Leaf } \\
\text { spectra }\end{array}$ & Phenology & Status \\
\hline \multirow[t]{2}{*}{ Cannabaceae } & $\begin{array}{l}\text { Cannabis sativa } \\
\text { L. / NK236 }\end{array}$ & Bhang & $\mathrm{H}$ & Th & Mep & Apr-Sep & Native ${ }^{\mathrm{VC}}$, In \\
\hline & $\begin{array}{c}\text { Celtis australis L. } \\
\text { / NK237 }\end{array}$ & Kharik & $\mathrm{T}$ & Ms & Mip & Mar-May & Native Ra, NI \\
\hline \multirow[t]{2}{*}{ Caprifoliaceae } & $\begin{array}{c}\text { Valeriana } \\
\text { jatamansi Jones / } \\
\text { NK238 }\end{array}$ & Mushkbala & $\mathrm{H}$ & G & Mip & Mar-May & Native ${ }^{\mathrm{Co}, \mathrm{NI}}$ \\
\hline & $\begin{array}{c}\text { Lonicera } \\
\text { quinquelocularis } \\
\text { Hard. / NK239 }\end{array}$ & Phutt & S & $\mathrm{Mc}$ & Mip & Apr-Jul & Native ${ }^{\mathrm{Co}, \mathrm{NI}}$ \\
\hline \multirow[t]{2}{*}{ Caryophyllaceae } & $\begin{array}{c}\text { Silene conoidea } \mathrm{L} . \\
\text { / NK240 }\end{array}$ & Dabbri & $\mathrm{H}$ & Th & Nap & Mar-Apr & Native ${ }^{\text {Ra, NI }}$ \\
\hline & $\begin{array}{l}\text { Stellaria media } \\
\text { (L.) Vill. / NK241 }\end{array}$ & Lausari & $\mathrm{H}$ & Th & Nap & Apr-Aug & Native ${ }^{\mathrm{VC}, \text { In }}$ \\
\hline Celastraceae & $\begin{array}{l}\text { Gymnosporia } \\
\text { royleana Wall. ex } \\
\text { M.A. Lawson / } \\
\text { NK242 }\end{array}$ & Patakhi & $S$ & $\mathrm{~Np}$ & Nap & Sep-Jan & Native ${ }^{R a, N I}$ \\
\hline \multirow[t]{12}{*}{ Compositae } & $\begin{array}{c}\text { Achillea } \\
\text { millefolium L. / } \\
\text { NK190 }\end{array}$ & Sultan booti & $\mathrm{H}$ & Th & Mip & Jul-Sep & Native $\mathrm{VC}, \mathrm{NI}$ \\
\hline & $\begin{array}{c}\text { Anaphalis } \\
\text { triplinervis (Sims) } \\
\text { Sims ex C.B. } \\
\text { Clarke / NK191 }\end{array}$ & Unavailable & $\mathrm{H}$ & G & Mip & Jul-Oct & Native ${ }^{\mathrm{VR}, \mathrm{NI}}$ \\
\hline & $\begin{array}{c}\text { Artemisia } \\
\text { absinthium L. / } \\
\text { NK192 }\end{array}$ & Chaoo & $\mathrm{H}$ & $\mathrm{Ch}$ & Mip & Jun-Sep & Native ${ }^{R a, N I}$ \\
\hline & $\begin{array}{c}\text { Artemisia } \\
\text { scoparia } \text { Waldst. } \\
\text { \& Kitam. / NK193 }\end{array}$ & Marua & $\mathrm{H}$ & $\mathrm{Ch}$ & Lep & Jul-Nov & Native ${ }^{R a, N I}$ \\
\hline & $\begin{array}{c}\text { Artemisia vulgaris } \\
\text { L. / NK194 }\end{array}$ & Chaoo & $\mathrm{H}$ & $\mathrm{Ch}$ & Mip & Aug-Nov & Native $^{\mathrm{Co}, \mathrm{NI}}$ \\
\hline & $\begin{array}{c}\text { Aster alpinus L. I } \\
\text { NK195 }\end{array}$ & Alpine aster & $\mathrm{H}$ & Th & Mip & May-Jun & Introduced VR, NI \\
\hline & $\begin{array}{l}\text { Aster flaccidus } \\
\text { Bunge / NK196 }\end{array}$ & Unavailable & $\mathrm{H}$ & Th & Nap & Jul-Sep & Native ${ }^{\mathrm{Co}, \mathrm{NI}}$ \\
\hline & $\begin{array}{l}\text { Bidens bipinnata } \\
\text { L. / NK197 }\end{array}$ & Surela & $\mathrm{H}$ & Th & Mip & Jun-Oct & Introduced $\mathrm{VC}$, In \\
\hline & $\begin{array}{c}\text { Bidens pilosa } \mathrm{L} . / \\
\text { NK198 }\end{array}$ & Surela & $\mathrm{H}$ & Th & Mip & May-Oct & Introduced ${ }^{\mathrm{VC}, \text { In }}$ \\
\hline & $\begin{array}{c}\text { Carpesium } \\
\text { abrotanoides L. / } \\
\text { NK199 }\end{array}$ & Unavailable & $\mathrm{H}$ & $\mathrm{Np}$ & Mep & Sep-Nov & Native ${ }^{\mathrm{Co}, \mathrm{NI}}$ \\
\hline & $\begin{array}{l}\text { Carpesium } \\
\text { cernuum L. / } \\
\text { NK200 }\end{array}$ & Unavailable & $\mathrm{H}$ & Th & Mep & Jun-Aug & Native VC, NI \\
\hline & $\begin{array}{l}\text { Cirsium arvense } \\
\text { (L.) Scop. / } \\
\text { NK201 }\end{array}$ & Tattaar & $\mathrm{H}$ & Th & Mep & Aug-Oct & Native $^{\mathrm{Co}, \mathrm{In}}$ \\
\hline
\end{tabular}




\begin{tabular}{|c|c|c|c|c|c|c|c|}
\hline \multirow[t]{19}{*}{ Family } & $\begin{array}{l}\text { Species names } \\
\text { and Voucher No. }\end{array}$ & Local name & Habit & $\begin{array}{l}\text { Life } \\
\text { forms }\end{array}$ & $\begin{array}{c}\text { Leaf } \\
\text { spectra }\end{array}$ & Phenology & Status \\
\hline & $\begin{array}{c}\text { Erigeron } \\
\text { bonariensis L. / } \\
\text { NK202 }\end{array}$ & Neeli booti & $\mathrm{H}$ & Th & Nap & Jun-Nov & Introduced $\mathrm{VC}$, In \\
\hline & $\begin{array}{l}\text { Erigeron trilobus } \\
\text { (Decne.) Boiss. / } \\
\text { NK203 }\end{array}$ & Paleet & $\mathrm{H}$ & Th & Lep & Sep-Oct & Native Ra, NI \\
\hline & $\begin{array}{c}\text { Galinsoga } \\
\text { parviflora Cav. / } \\
\text { NK204 }\end{array}$ & $\begin{array}{l}\text { Gallant } \\
\text { soldiers }\end{array}$ & $\mathrm{H}$ & $\mathrm{Th}$ & Mip & Jul-Oct & Introduced $\mathrm{VC}$, In \\
\hline & $\begin{array}{c}\text { Gerbera } \\
\text { gossypina (Royle) } \\
\text { Beauverd / NK205 }\end{array}$ & Phutkola & $\mathrm{H}$ & $\mathrm{Hc}$ & Mep & May-Jul & Native ${ }^{\mathrm{VC}, \mathrm{NI}}$ \\
\hline & $\begin{array}{c}\text { Himalaiella } \\
\text { heteromalla (D. } \\
\text { Don) Raab- } \\
\text { Straube / NK206 }\end{array}$ & Gwaal mula & $\mathrm{H}$ & $\mathrm{Hc}$ & Mip & Jun-Aug & Native ${ }^{\mathrm{VC}, \mathrm{NI}}$ \\
\hline & $\begin{array}{c}\text { Jurinea dolomiaea } \\
\text { Boiss. / NK207 }\end{array}$ & Gugal toof & $\mathrm{H}$ & $\mathrm{Hc}$ & Mip & Jul-Sep & Native $\mathrm{VR}, \mathrm{NI}$ \\
\hline & $\begin{array}{l}\text { Kalimeris altaica } \\
\text { (Willd.) Nees ex } \\
\text { Fisch. Mey. \& } \\
\text { Ave-Lall. / } \\
\text { NK208 }\end{array}$ & Unavailable & $\mathrm{H}$ & Th & Nap & Jul-Oct & Native ${ }^{\mathrm{Co}, \mathrm{NI}}$ \\
\hline & $\begin{array}{c}\text { Launaea } \\
\text { nudicaulis Hook. } \\
\text { f. / NK209 }\end{array}$ & Dudhal & $\mathrm{H}$ & Th & Mep & Apr-Jun & Native Ra, NI \\
\hline & $\begin{array}{c}\text { Leontopodium } \\
\text { himalayanum DC. } \\
\text { / NK210 }\end{array}$ & Silver star & $\mathrm{H}$ & Th & Nap & Jul-Oct & Native $\mathrm{VR}, \mathrm{NI}$ \\
\hline & $\begin{array}{c}\text { Myriactis } \\
\text { nepalensis Less. / } \\
\text { NK211 }\end{array}$ & Thuke phool & $\mathrm{H}$ & Th & Mip & Apr-Nov & Native ${ }^{\mathrm{VC}, \mathrm{NI}}$ \\
\hline & $\begin{array}{l}\text { Myriactis wightii } \\
\text { DC. / NK212 }\end{array}$ & Thuke phool & $\mathrm{H}$ & Th & Mip & Jul-Nov & Native ${ }^{\mathrm{Co}, \mathrm{NI}}$ \\
\hline & $\begin{array}{c}\text { Parthenium } \\
\text { hysterophorus L. / } \\
\text { NK213 }\end{array}$ & Gandi booti & $\mathrm{H}$ & Th & Nap & Apr-Aug & Introduced $\mathrm{VC}$, In \\
\hline & $\begin{array}{c}\text { Phagnalon } \\
\text { rupestre (L.) DC. / } \\
\text { NK214 }\end{array}$ & Unavailable & $\mathrm{H}$ & Th & Mip & Mar-May & Native $\mathrm{VR}, \mathrm{NI}$ \\
\hline & $\begin{array}{c}\text { Prenanthes } \\
\text { brunoniana Wall. } \\
\text { ex DC. / NK215 }\end{array}$ & Duddal & $\mathrm{H}$ & Th & Mep & Aug-Sep & Native ${ }^{\mathrm{VC}, \mathrm{NI}}$ \\
\hline & $\begin{array}{l}\text { Siegesbeckia } \\
\text { orientalis L. / } \\
\text { NK216 }\end{array}$ & $\begin{array}{c}\text { Yellow } \\
\text { crown beared }\end{array}$ & $\mathrm{H}$ & Th & Mep & Oct-Nov & Native ${ }^{\mathrm{Co}, \mathrm{NI}}$ \\
\hline & $\begin{array}{c}\text { Silybum } \\
\text { marianum (L.) } \\
\text { Gaertn. / NK217 }\end{array}$ & Kandyari & $\mathrm{H}$ & Th & Mep & Feb-Apr & Native ${ }^{\mathrm{VC}, \text { In }}$ \\
\hline & $\begin{array}{c}\text { Solidago } \\
\text { virgaurea } \text { L. / } \\
\text { NK218 }\end{array}$ & Woundwort & $\mathrm{H}$ & $\mathrm{Hc}$ & Mip & Jul-Oct & Native ${ }^{\mathrm{Co}, \mathrm{NI}}$ \\
\hline & $\begin{array}{l}\text { Sonchus asper } \\
\text { (L.) Hill / NK219 }\end{array}$ & Dudhal & $\mathrm{H}$ & Th & Mep & Mar-Oct & Native ${ }^{\mathrm{VC}, \mathrm{NI}}$ \\
\hline
\end{tabular}




$$
-328-
$$

\begin{tabular}{|c|c|c|c|c|c|c|c|}
\hline Family & $\begin{array}{c}\text { Species names } \\
\text { and Voucher No. }\end{array}$ & Local name & Habit & $\begin{array}{l}\text { Life } \\
\text { forms }\end{array}$ & $\begin{array}{l}\text { Leaf } \\
\text { spectra }\end{array}$ & Phenology & Status \\
\hline & $\begin{array}{l}\text { Sonchus oleraceus } \\
\text { (L.) L. / NK220 }\end{array}$ & Dudhal & $\mathrm{H}$ & Th & Mep & Mar-Jun & Native ${ }^{\mathrm{Co}, \mathrm{NI}}$ \\
\hline & $\begin{array}{c}\text { Tagetes minuta } \mathrm{L} . \\
\text { / NK221 }\end{array}$ & Sadbarga & $\mathrm{H}$ & Th & Mip & Oct-Nov & Introduced $\mathrm{VC}$, In \\
\hline & $\begin{array}{c}\text { Taraxacum } \\
\text { campylodes G.E. } \\
\text { Haglund / NK222 }\end{array}$ & Hand & $\mathrm{H}$ & $\mathrm{Hc}$ & Mip & Mar-Sep & Introduced $\mathrm{VC}$, In \\
\hline & $\begin{array}{c}\text { Xanthium } \\
\text { strumarium L. / } \\
\text { NK223 }\end{array}$ & Kandeli & $\mathrm{H}$ & Th & Mep & Aug-Oct & Introduced $\mathrm{VC}$, In \\
\hline \multirow[t]{5}{*}{ Convolvulaceae } & $\begin{array}{l}\text { Convolvulus } \\
\text { arvensis L. / } \\
\text { NK243 }\end{array}$ & Do tilla & $\mathrm{C}$ & $\mathrm{L}$ & Mip & May-Sep & Native ${ }^{\mathrm{VC}, \mathrm{NI}}$ \\
\hline & $\begin{array}{l}\text { Cuscuta australis } \\
\text { R. Br. / NK244 }\end{array}$ & Neela taari & $\mathrm{C}$ & $\mathrm{L}$ & Lep & Aug-Oct & Introduced ${ }^{\mathrm{Ra}, \mathrm{NI}}$ \\
\hline & $\begin{array}{l}\text { Cuscuta reflexa } \\
\text { Roxb. / NK245 }\end{array}$ & Neela taari & $\mathrm{C}$ & $\mathrm{L}$ & Lep & Aug-Oct & Native ${ }^{\mathrm{Co}, \mathrm{NI}}$ \\
\hline & $\begin{array}{l}\text { Ipomoea carnea } \\
\text { Jacq. / NK246 }\end{array}$ & Jangli bekarh & $S$ & $\mathrm{~Np}$ & Mep & Jul-Nov & Introduced ${ }^{\mathrm{Ra}, \mathrm{NI}}$ \\
\hline & $\begin{array}{l}\text { Ipomoea purpurea } \\
\text { (L.) Roth / NK247 }\end{array}$ & Eerh & $\mathrm{C}$ & Th & Mep & Jul-Sep & Introduced ${ }^{\mathrm{Co}, \mathrm{NI}}$ \\
\hline Cornaceae & $\begin{array}{c}\text { Cornus } \\
\text { macrophylla Wall. } \\
\text { / NK248 }\end{array}$ & Qandar & $\mathrm{T}$ & Ms & Mep & Apr-Jun & Native ${ }^{\mathrm{VR}, \mathrm{NI}}$ \\
\hline Cucurbitaceae & $\begin{array}{c}\text { Solena } \\
\text { amplexicaulis } \\
\text { (Lam.) Gandhi / } \\
\text { NK249 }\end{array}$ & Gwal khakhri & $\mathrm{C}$ & $\mathrm{L}$ & Mep & Apr-Jul & Native VR, NI \\
\hline \multirow[t]{2}{*}{ Ebenaceae } & $\begin{array}{c}\text { Diospyros kaki } \\
\text { L.f. / NK250 }\end{array}$ & Mota amlook & $\mathrm{T}$ & Ms & Mep & May-Aug & Introduced ${ }^{\mathrm{Co}, \mathrm{NI}}$ \\
\hline & $\begin{array}{l}\text { Diospyros lotus L. } \\
\text { / NK251 }\end{array}$ & Amlook & $\mathrm{T}$ & Ms & Mep & May-Jun & Native ${ }^{\mathrm{VC}, \mathrm{NI}}$ \\
\hline Elaeagnaceae & $\begin{array}{c}\text { Elaeagnus } \\
\text { umbellata Thunb. } \\
\text { / NK252 }\end{array}$ & Kankoli & $S$ & $\mathrm{Mc}$ & Mip & May-Jun & Native ${ }^{\mathrm{Co}, \mathrm{NI}}$ \\
\hline \multirow[t]{6}{*}{ Euphorbiaceae } & $\begin{array}{c}\text { Euphorbia } \\
\text { granulata Forssk. } \\
\text { / NK253 }\end{array}$ & Hazar dani & $\mathrm{H}$ & Th & Lep & Jun-Sep & Native ${ }^{\mathrm{Co}, \mathrm{NI}}$ \\
\hline & $\begin{array}{c}\text { Euphorbia } \\
\text { helioscopia L. / } \\
\text { NK254 }\end{array}$ & Dhudal & $\mathrm{H}$ & Th & Nap & Jan-Jul & Native $\mathrm{VC}$, In \\
\hline & $\begin{array}{c}\text { Euphorbia } \\
\text { heterophylla L. / } \\
\text { NK255 }\end{array}$ & Milk weed & $\mathrm{H}$ & Th & Mip & Aug-Sep & Introduced ${ }^{\mathrm{Co}, \mathrm{NI}}$ \\
\hline & $\begin{array}{l}\text { Euphorbia hirta } \\
\text { L. / NK256 }\end{array}$ & Dudhali & $\mathrm{H}$ & $\mathrm{Th}$ & Nap & Jul-Dec & Introduced ${ }^{\mathrm{Co}, \text { In }}$ \\
\hline & $\begin{array}{c}\text { Euphorbia } \\
\text { prostrata Aiton / } \\
\text { NK257 }\end{array}$ & Hazaar dani & $\mathrm{H}$ & $\mathrm{Th}$ & Lep & Apr-Oct & Introduced $\mathrm{Co}, \mathrm{NI}$ \\
\hline & $\begin{array}{c}\text { Mallotus } \\
\text { philippensis }\end{array}$ & Kamela & $\mathrm{T}$ & $\mathrm{Mc}$ & Mep & Mar-May & Native ${ }^{\mathrm{Co}, \mathrm{NI}}$ \\
\hline
\end{tabular}




\begin{tabular}{|c|c|c|c|c|c|c|c|}
\hline Family & $\begin{array}{c}\text { Species names } \\
\text { and Voucher No. }\end{array}$ & Local name & Habit & $\begin{array}{c}\text { Life } \\
\text { forms }\end{array}$ & $\begin{array}{c}\text { Leaf } \\
\text { spectra }\end{array}$ & Phenology & Status \\
\hline & $\begin{array}{l}\text { (Lam.) Müll.Arg. / } \\
\text { NK258 }\end{array}$ & & & & & & \\
\hline & $\begin{array}{l}\text { Ricinus communis } \\
\text { L. / NK259 }\end{array}$ & Arind & $\mathrm{H}$ & $\mathrm{Mc}$ & Mep & Jun-Sep & Introduced ${ }^{\mathrm{VC}}$, In \\
\hline \multirow[t]{2}{*}{ Fagaceae } & $\begin{array}{l}\text { Quercus baloot } \\
\text { Griff. / NK274 }\end{array}$ & Parungi & $\mathrm{T}$ & Ms & Mep & Apr-May & Native ${ }^{\mathrm{VC}, \mathrm{NI}}$ \\
\hline & $\begin{array}{l}\text { Quercus incana } \\
\text { Bartram / NK275 }\end{array}$ & Reen & $\mathrm{T}$ & Ms & Mep & Apr-May & Native ${ }^{\mathrm{VC}, \mathrm{NI}}$ \\
\hline \multirow[t]{3}{*}{ Gentianaceae } & $\begin{array}{c}\text { Gentiana } \\
\text { squarrosa Ledeb. } \\
\text { / NK276 }\end{array}$ & Unavailable & $\mathrm{H}$ & Th & Nap & Apr-Sep & Native ${ }^{\mathrm{VC}, \mathrm{NI}}$ \\
\hline & $\begin{array}{c}\text { Swertia } \\
\text { angustifolia } \\
\text { Buch.-Ham. ex D. } \\
\text { Don / NK277 }\end{array}$ & Choratta & $\mathrm{H}$ & $\mathrm{Th}$ & Mip & Jun-Nov & Native $\mathrm{VC}, \mathrm{NI}$ \\
\hline & $\begin{array}{c}\text { Swertia chirayita } \\
\text { (Roxb.) Buch.- } \\
\text { Ham. ex } \\
\text { C.B.Clarke / } \\
\text { NK278 }\end{array}$ & Choratta & $\mathrm{H}$ & $\mathrm{Th}$ & Mip & Jul-Oct & Native $^{\mathrm{Ra}, \mathrm{NI}}$ \\
\hline \multirow[t]{2}{*}{ Geraniaceae } & $\begin{array}{c}\text { Geranium } \\
\text { nepalense Sweet / } \\
\text { NK279 }\end{array}$ & Rattan doi & $\mathrm{H}$ & $\mathrm{Hc}$ & Mip & Apr-Sep & Native ${ }^{\mathrm{Co}, \mathrm{NI}}$ \\
\hline & $\begin{array}{c}\text { Geranium } \\
\text { wallichianum D. } \\
\text { Don ex Sweet / } \\
\text { NK280 }\end{array}$ & Rattan do & $\mathrm{H}$ & Th & Mip & Jul-Sep & Native ${ }^{\mathrm{VC}, \mathrm{NI}}$ \\
\hline Hypericaceae & $\begin{array}{c}\text { Hypericum } \\
\text { perforatum } \mathrm{L} . / \\
\text { NK281 }\end{array}$ & Sharan gulab & $\mathrm{H}$ & $\mathrm{Ch}$ & Nap & Jun-Sep & Native ${ }^{\mathrm{Co}, \mathrm{NI}}$ \\
\hline Juglandaceae & $\begin{array}{c}\text { Juglans regia L. / } \\
\text { NK282 }\end{array}$ & Akhor & $\mathrm{T}$ & Ms & Mep & Feb-Apr & Native ${ }^{\mathrm{VC}, \mathrm{NI}}$ \\
\hline \multirow[t]{7}{*}{ Lamiaceae } & $\begin{array}{c}\text { Ajuga integrifolia } \\
\text { Buch.-Ham / } \\
\text { NK283 }\end{array}$ & Ratti booti & $\mathrm{H}$ & $\mathrm{Hc}$ & Mip & Mar-Jun & Native Ra, NI \\
\hline & $\begin{array}{l}\text { Ajuga parviflora } \\
\text { Benth. / NK284 }\end{array}$ & Ratti booti & $\mathrm{H}$ & $\mathrm{Th}$ & Mep & Mar-Jun & Native ${ }^{\mathrm{Co}, \mathrm{NI}}$ \\
\hline & $\begin{array}{c}\text { Callicarpa } \\
\text { macrophylla Vahl } \\
\text { / NK285 }\end{array}$ & Ukkal & $\mathrm{T}$ & Ms & Mep & Jul-Nov & Native ${ }^{\mathrm{Co}, \mathrm{NI}}$ \\
\hline & $\begin{array}{c}\text { Clinopodium } \\
\text { debile (Bunge) } \\
\text { Kuntze / NK286 }\end{array}$ & Unavailable & $\mathrm{H}$ & $\mathrm{Hc}$ & Nap & Aug-Sep & Native $\mathrm{VR}, \mathrm{NI}$ \\
\hline & $\begin{array}{c}\text { Clinopodium } \\
\text { umbrosum (M. } \\
\text { Bieb.) Kuntze / } \\
\text { NK287 }\end{array}$ & Unavailable & $\mathrm{H}$ & $\mathrm{Hc}$ & Nap & May-Jul & Native ${ }^{\mathrm{VC}, \mathrm{NI}}$ \\
\hline & $\begin{array}{l}\text { Clinopodium } \\
\text { vulgare L. / } \\
\text { NK288 }\end{array}$ & Unavailable & $\mathrm{H}$ & $\mathrm{Th}$ & Mip & Mar-Jul & Native ${ }^{\mathrm{Co}, \mathrm{NI}}$ \\
\hline & $\begin{array}{l}\text { Isodon coetsa } \\
\text { (Buch.-Ham. ex }\end{array}$ & Unavailable & $\mathrm{H}$ & $\mathrm{Ch}$ & Mip & Aug-Sep & Native ${ }^{\mathrm{VC}, \mathrm{NI}}$ \\
\hline
\end{tabular}




\begin{tabular}{|c|c|c|c|c|c|c|c|}
\hline \multirow[t]{17}{*}{ Family } & $\begin{array}{c}\text { Species names } \\
\text { and Voucher No. }\end{array}$ & Local name & Habit & $\begin{array}{c}\text { Life } \\
\text { forms }\end{array}$ & $\begin{array}{c}\text { Leaf } \\
\text { spectra }\end{array}$ & Phenology & Status \\
\hline & $\begin{array}{l}\text { D. Don) Kudo / } \\
\text { NK289 }\end{array}$ & & & & & & \\
\hline & $\begin{array}{l}\text { Isodon rugosus } \\
\text { (Wall. ex Benth.) } \\
\text { Codd / NK290 }\end{array}$ & Pissu maar & $S$ & $\mathrm{~Np}$ & Mip & Mar-Oct & Native ${ }^{\mathrm{VC}, \mathrm{NI}}$ \\
\hline & $\begin{array}{l}\text { Mentha arvensis } \\
\text { L. / NK291 }\end{array}$ & Bareena & $\mathrm{H}$ & $\mathrm{Hc}$ & Mip & Jul-Sep & Native ${ }^{\mathrm{Co}, \mathrm{NI}}$ \\
\hline & $\begin{array}{l}\text { Mentha longifolia } \mathrm{F} \\
\text { (L.) L. / NK292 }\end{array}$ & $\begin{array}{l}\text { Pootna, chitta } \\
\text { podina }\end{array}$ & $\mathrm{H}$ & $\mathrm{Hc}$ & Mip & May-Nov & Native ${ }^{\mathrm{Co}, \mathrm{NI}}$ \\
\hline & $\begin{array}{c}\text { Micromeria } \\
\text { biflora (Buch.- } \\
\text { Ham. ex D. Don) } \\
\text { Benth. / NK293 } \\
\end{array}$ & Jarhi & $\mathrm{H}$ & $\mathrm{Hc}$ & Lep & Mar-Nov & Native ${ }^{\mathrm{VC}, \mathrm{NI}}$ \\
\hline & $\begin{array}{l}\text { Nepeta cataria L. } \\
\text { / NK294 }\end{array}$ & Cat mint & $\mathrm{H}$ & $\mathrm{Hc}$ & Mep & Jun-Jul & Native ${ }^{\mathrm{Co}, \mathrm{NI}}$ \\
\hline & $\begin{array}{c}\text { Nepeta govaniana } \\
\text { (Wall. ex Benth.) } \\
\text { Benth. / NK295 }\end{array}$ & Ladori & $\mathrm{H}$ & $\mathrm{Hc}$ & Nap & Jul-Sep & Native ${ }^{R a, N I}$ \\
\hline & $\begin{array}{l}\text { Nepeta laevigata } \\
\text { (D. Don) Hand.- } \\
\text { Mazz. / NK296 }\end{array}$ & Unavailable & $\mathrm{H}$ & $\mathrm{Hc}$ & Mip & Jun-Aug & Native ${ }^{\mathrm{Co}, \mathrm{NI}}$ \\
\hline & $\begin{array}{l}\text { Origanum vulgare } \\
\text { L. / NK297 }\end{array}$ & Maskanna & $\mathrm{H}$ & $\mathrm{Hc}$ & Nap & Jun-Oct & Native ${ }^{\mathrm{VC}, \mathrm{NI}}$ \\
\hline & $\begin{array}{l}\text { Prunella vulgaris } \\
\text { L. / NK298 }\end{array}$ & Nariya & $\mathrm{H}$ & $\mathrm{Hc}$ & Mip & Jun-Aug & Native ${ }^{\mathrm{Co}, \mathrm{NI}}$ \\
\hline & $\begin{array}{l}\text { Rydingia limbata } \\
\text { (Benth.) Scheen \& } \\
\text { V. A. Albert / } \\
\text { NK299 }\end{array}$ & Chitta jand & $S$ & $\mathrm{~Np}$ & Mip & Apr-May & Native ${ }^{\mathrm{Co}, \mathrm{NI}}$ \\
\hline & $\begin{array}{l}\text { Salvia canariensis } \\
\text { L. / NK300 }\end{array}$ & Kathra & $\mathrm{H}$ & $\mathrm{Hc}$ & Mip & Apr-Jul & Native ${ }^{\mathrm{Co}, \mathrm{NI}}$ \\
\hline & $\begin{array}{c}\text { Salvia } \\
\text { moorcroftiana } \\
\text { Wall. ex Benth./ } \\
\text { NK301 }\end{array}$ & Kathra & $\mathrm{H}$ & $\mathrm{Hc}$ & Mep & May-Jun & Native ${ }^{R a, N I}$ \\
\hline & $\begin{array}{c}\text { Salvia nubicola } \\
\text { Wall. ex Sweet / } \\
\text { NK302 }\end{array}$ & Noorchari & $\mathrm{H}$ & $\mathrm{Hc}$ & Mep & Jun-Oct & Native ${ }^{R a, N I}$ \\
\hline & $\begin{array}{c}\text { Scutellaria grossa } \\
\text { Wall. / NK303 }\end{array}$ & Mastiari & $\mathrm{H}$ & $\mathrm{Hc}$ & Mip & Jul-Sep & Native ${ }^{\mathrm{Co}, \mathrm{NI}}$ \\
\hline & $\begin{array}{l}\text { Thymus linearis } \\
\text { Benth. / NK304 }\end{array}$ & Chikal & $\mathrm{H}$ & $\mathrm{Ch}$ & Lep & Jul-Aug & Native $^{\mathrm{Ra}, \mathrm{NI}}$ \\
\hline \multirow[t]{3}{*}{ Leguminosae } & $\begin{array}{l}\text { Acacia nilotica } \\
\text { (L.) Delile / } \\
\text { NK260 }\end{array}$ & Kikar & $\mathrm{T}$ & Ms & Mip & Mar-Aug & Native ${ }^{\mathrm{VC}, \text { In }}$ \\
\hline & $\begin{array}{c}\text { Astragalus } \\
\text { grahamianus } \\
\text { Benth. / NK261 }\end{array}$ & $\begin{array}{c}\text { Kala } \\
\text { kandyara }\end{array}$ & $\mathrm{H}$ & $\mathrm{Ch}$ & Mep & Apr-Aug & Native Ra, NI \\
\hline & $\begin{array}{c}\text { Crotalaria } \\
\text { medicaginea Lam. } \\
\text { / NK262 }\end{array}$ & Sinji & $\mathrm{H}$ & Th & Mip & Mar-Aug & Native ${ }^{\mathrm{Co}, \mathrm{NI}}$ \\
\hline
\end{tabular}




\begin{tabular}{|c|c|c|c|c|c|c|c|}
\hline Family & $\begin{array}{c}\text { Species names } \\
\text { and Voucher No. }\end{array}$ & Local name & Habit & $\begin{array}{l}\text { Life } \\
\text { forms }\end{array}$ & $\begin{array}{c}\text { Leaf } \\
\text { spectra }\end{array}$ & Phenology & Status \\
\hline & $\begin{array}{c}\text { Dalbergia sissoo } \\
\text { DC. / NK263 }\end{array}$ & $\begin{array}{c}\text { Tahli, } \\
\text { Sheesham }\end{array}$ & $\mathrm{T}$ & Ms & Mip & Mar-May & Native ${ }^{\mathrm{Co}, \mathrm{NI}}$ \\
\hline & $\begin{array}{c}\text { Desmodium } \\
\text { elegans DC. / } \\
\text { NK264 }\end{array}$ & Chamkath & $S$ & $\mathrm{~Np}$ & Mep & Jun-Sep & Native Ra, NI \\
\hline & $\begin{array}{c}\text { Indigofera } \\
\text { heterantha } \\
\text { Brandis / NK265 }\end{array}$ & Jandh & $S$ & $\mathrm{~Np}$ & Lep & May-Jul & Native VC, In \\
\hline & $\begin{array}{c}\text { Indigofera } \\
\text { linifolia (L. f.) } \\
\text { Retz. / NK266 }\end{array}$ & Nikki kawati & $\mathrm{H}$ & $\mathrm{Th}$ & Nap & Jul-Oct & Native $^{\text {Ra, NI }}$ \\
\hline & $\begin{array}{l}\text { Lespedeza juncea } \\
\text { var. sericea } \\
\text { (Thunb.) Lace \& } \\
\text { Hauech / NK267 }\end{array}$ & Jandi & $\mathrm{H}$ & $\mathrm{Ch}$ & Nap & Jul-Oct & Native ${ }^{\mathrm{VC}, \mathrm{NI}}$ \\
\hline & $\begin{array}{c}\text { Lespedeza bicolor } \\
\text { Turcz. / NK268 }\end{array}$ & Chamkaath & $\mathrm{S}$ & $\mathrm{Np}$ & Mep & Jul-Sep & Native Ra, NI \\
\hline & $\begin{array}{l}\text { Lotus corniculatus } \\
\text { L. / NK269 }\end{array}$ & Peela palti & $\mathrm{H}$ & $\mathrm{Hc}$ & Nap & Apr-Aug & Native ${ }^{\mathrm{Co}, \mathrm{NI}}$ \\
\hline & $\begin{array}{c}\text { Medicago } \\
\text { polymorpha L. / } \\
\text { NK270 }\end{array}$ & Maina & $\mathrm{H}$ & $\mathrm{Th}$ & Mip & Mar-May & Native VC, In \\
\hline & $\begin{array}{c}\text { Mimosa } \\
\text { himalayana } \\
\text { Gamble / NK271 }\end{array}$ & Arai & $\mathrm{S}$ & $\mathrm{Np}$ & Nap & Jun-Aug & Native ${ }^{R a, N I}$ \\
\hline & $\begin{array}{c}\text { Oxytropis } \\
\text { lapponica } \\
\text { (Wahlenb.) Gay / } \\
\text { NK272 }\end{array}$ & Jandi & $\mathrm{H}$ & $\mathrm{Ch}$ & Nap & Jun-Aug & Native Ra, NI \\
\hline & $\begin{array}{l}\text { Trifolium repens } \\
\text { L. / NK } 273\end{array}$ & Khatimal & $\mathrm{H}$ & $\mathrm{Hc}$ & Mip & Apr-Jul & Native VC, In \\
\hline Linaceae & $\begin{array}{c}\text { Linum } \\
\text { corymbulosum } \\
\text { Rchb. / NK305 }\end{array}$ & Tangra & $\mathrm{H}$ & $\mathrm{Ch}$ & Mip & Mar-Jun & Native Ra, NI \\
\hline Lythraceae & $\begin{array}{l}\text { Punica granatum } \\
\text { L. / NK306 }\end{array}$ & Daarhu & $\mathrm{S}$ & $\mathrm{Np}$ & Mip & Apr-Jun & Native VC, NI \\
\hline \multirow[t]{4}{*}{ Malvaceae } & $\begin{array}{l}\text { Corchorus tridens } \\
\text { L. / NK307 }\end{array}$ & Unavailable & $\mathrm{H}$ & $\mathrm{Th}$ & Mip & Jul-Nov & Native Ra, NI \\
\hline & $\begin{array}{c}\text { Grewia optiva J.R. } \\
\text { Drumm. ex Burret } \\
\text { / NK308 }\end{array}$ & Taman & $\mathrm{T}$ & Ms & Mep & Apr-Sep & Native ${ }^{\mathrm{Co}, \mathrm{NI}}$ \\
\hline & $\begin{array}{l}\text { Malva neglecta } \\
\text { Wallr. / NK309 }\end{array}$ & Sonchal & $\mathrm{H}$ & Th & Mip & Jun-Sep & Native ${ }^{\mathrm{Co}, \mathrm{NI}}$ \\
\hline & $\begin{array}{c}\text { Malvastrum } \\
\text { coromandelianum } \\
\text { (L.) Garcke / } \\
\text { NK310 }\end{array}$ & Gogi booti & $\mathrm{H}$ & $\mathrm{Th}$ & Mip & Jun-Sep & Introduced ${ }^{\mathrm{Co}, \mathrm{NI}}$ \\
\hline Meliaceae & $\begin{array}{l}\text { Melia azedarach } \\
\text { L. / NK311 }\end{array}$ & Daraik & $\mathrm{T}$ & Ms & Mep & Mar-Apr & Introduced $\mathrm{VC}$, In \\
\hline Moraceae & $\begin{array}{c}\text { Broussonetia } \\
\text { papyrifera }(\mathrm{L} .)\end{array}$ & Jangli toot & $\mathrm{T}$ & Ms & Mep & Mar-Aug & Introduced VC, In \\
\hline
\end{tabular}




\begin{tabular}{|c|c|c|c|c|c|c|c|}
\hline Family & $\begin{array}{c}\text { Species names } \\
\text { and Voucher No. }\end{array}$ & Local name & Habit & $\begin{array}{l}\text { Life } \\
\text { forms }\end{array}$ & $\begin{array}{c}\text { Leaf } \\
\text { spectra }\end{array}$ & Phenology & Status \\
\hline & \multicolumn{7}{|l|}{$\begin{array}{l}\text { L’Her. ex Vent. / } \\
\text { NK312 }\end{array}$} \\
\hline & $\begin{array}{c}\text { Ficus carica } \mathrm{L} . / \\
\text { NK313 }\end{array}$ & $\begin{array}{l}\text { Teen patri } \\
\text { phagwari }\end{array}$ & $\mathrm{T}$ & $\mathrm{Mc}$ & Mep & Apr-Dec & Native ${ }^{\mathrm{Co}, \mathrm{NI}}$ \\
\hline & $\begin{array}{l}\text { Ficus palmata } \\
\text { Forssk. / NK314 }\end{array}$ & Phagwari & $\mathrm{T}$ & Ms & Mep & May-Sep & Native ${ }^{\mathrm{VC}, \mathrm{NI}}$ \\
\hline & $\begin{array}{c}\text { Ficus sarmentosa } \\
\text { Buch.-Ham. ex. } \\
\text { Sm. / NK315 }\end{array}$ & Dadday veil & $\mathrm{C}$ & $\mathrm{L}$ & Mip & May-Sep & Native $\mathrm{VR}, \mathrm{NI}$ \\
\hline & $\begin{array}{l}\text { Morus alba L. I } \\
\text { NK316 }\end{array}$ & Shaitoot & $\mathrm{T}$ & Ms & Mep & Apr-Sep & Introduced $\mathrm{VR}, \mathrm{NI}$ \\
\hline & $\begin{array}{c}\text { Morus nigra L. / } \\
\text { NK317 }\end{array}$ & Toot & $\mathrm{T}$ & Ms & Mep & Mar-Jul & Introduced ${ }^{\mathrm{Ra}, \mathrm{NI}}$ \\
\hline \multirow[t]{2}{*}{ Oleaceae } & $\begin{array}{l}\text { Jasminum humile } \\
\text { L. / NK318 }\end{array}$ & Chamba & S & $\mathrm{Np}$ & Mep & Apr-Jun & Native ${ }^{\mathrm{Co}, \mathrm{NI}}$ \\
\hline & $\begin{array}{c}\text { Olea ferruginea } \\
\text { Wall. ex Aitch. / } \\
\text { NK319 }\end{array}$ & Kaoo & $\mathrm{T}$ & Ms & Nap & Apr-May & Native ${ }^{\mathrm{VC}, \mathrm{NI}}$ \\
\hline Onagraceae & $\begin{array}{c}\text { Oenothera } \\
\text { rosea L' Her. ex } \\
\text { Aiton / NK320 }\end{array}$ & Ratt mundia & $\mathrm{H}$ & Th & Mip & Apr-Sep & Introduced $\mathrm{VC}$, In \\
\hline Oxalidaceae & $\begin{array}{l}\text { Oxalis corniculata } \\
\text { L. / NK321 }\end{array}$ & Khatti booti & $\mathrm{H}$ & $\mathrm{Hc}$ & Nap & Mar-Oct & Introduced VC, In \\
\hline Paeoniaceae & $\begin{array}{l}\text { Paeonia emodi } \\
\text { Royle / NK322 }\end{array}$ & Mameikh & $\mathrm{H}$ & $\mathrm{G}$ & Mep & May-Jun & Native VR, NI \\
\hline Papaveraceae & $\begin{array}{c}\text { Fumaria indica } \\
\text { (Hausskn.) } \\
\text { Pugsley / NK323 }\end{array}$ & Shatra papra & $\mathrm{H}$ & Th & Mip & Mar-Jun & Native ${ }^{\mathrm{Co}, \mathrm{NI}}$ \\
\hline Passifloraceae & $\begin{array}{l}\text { Passiflora } \\
\text { caerulea L. / } \\
\text { NK324 }\end{array}$ & $\begin{array}{l}\text { Garhi wala } \\
\text { phool }\end{array}$ & $\mathrm{C}$ & $\mathrm{L}$ & Mep & Jul-Sep & Introduced VR, NI \\
\hline Phyllanthaceae & $\begin{array}{c}\text { Leptopus } \\
\text { cordifolius Decne. } \\
\text { / NK325 }\end{array}$ & Karukni & S & $\mathrm{Np}$ & Mip & Jul-Oct & Native ${ }^{\mathrm{VC}, \mathrm{NI}}$ \\
\hline Phytolaccaceae & $\begin{array}{c}\text { Phytolacca } \\
\text { latbenia (Moq.) H. } \\
\text { Walter / NK326 }\end{array}$ & $\begin{array}{l}\text { Parth, Kala } \\
\text { kaath }\end{array}$ & $\mathrm{T}$ & Ms & Mep & Jun-Aug & Native VR, NI \\
\hline \multirow[t]{3}{*}{ Plantaginaceae } & $\begin{array}{c}\text { Plantago } \\
\text { lanceolata L. / } \\
\text { NK327 }\end{array}$ & Batti & $\mathrm{H}$ & $\mathrm{Hc}$ & Mip & Jul-Sep & Native ${ }^{\mathrm{VC}, \text { In }}$ \\
\hline & $\begin{array}{c}\text { Plantago major } \mathrm{L} . \\
\text { / NK328 }\end{array}$ & Isamgol & $\mathrm{H}$ & $\mathrm{Hc}$ & Mep & Aug-Sep & Native ${ }^{\mathrm{VC}, \text { In }}$ \\
\hline & $\begin{array}{l}\text { Veronica persica } \\
\text { Poir. / NK329 }\end{array}$ & Lazarh & $\mathrm{H}$ & Th & Mip & Feb-May & Introduced ${ }^{\mathrm{Co}, \mathrm{NI}}$ \\
\hline Platanaceae & $\begin{array}{c}\text { Platanus } \\
\text { orientalis L. / } \\
\text { NK330 }\end{array}$ & Chinaar & $\mathrm{T}$ & Ms & Mep & Apr-May & Introduced $\mathrm{VR}, \mathrm{NI}$ \\
\hline Polygalaceae & $\begin{array}{c}\text { Polygala } \\
\text { abyssinica } \text { R. Br. } \\
\text { ex Fresen. / } \\
\text { NK331 }\end{array}$ & Unavailable & $\mathrm{H}$ & $\mathrm{Ch}$ & Nap & Mar-Sep & Native ${ }^{\mathrm{Co}, \mathrm{NI}}$ \\
\hline
\end{tabular}




\begin{tabular}{|c|c|c|c|c|c|c|c|}
\hline Family & $\begin{array}{l}\text { Species names } \\
\text { and Voucher No. }\end{array}$ & Local name & Habit & $\begin{array}{c}\text { Life } \\
\text { forms }\end{array}$ & $\begin{array}{c}\text { Leaf } \\
\text { spectra }\end{array}$ & Phenology & Status \\
\hline \multirow[t]{8}{*}{ Polygonaceae } & $\begin{array}{c}\text { Persicaria } \\
\text { amplexicaulis (D. } \\
\text { Don) Ronse Decr. } \\
\text { / NK332 }\end{array}$ & Masloon & $\mathrm{H}$ & $\mathrm{Hc}$ & Mep & Jun-Sep & Native ${ }^{\mathrm{Co}, \mathrm{NI}}$ \\
\hline & $\begin{array}{c}\text { Persicaria } \\
\text { barbata }(\text { L.) H. } \\
\text { Hara / NK333 }\end{array}$ & Nariya & $\mathrm{H}$ & Th & Mip & Jun-Sep & Native ${ }^{\mathrm{VC}, \mathrm{NI}}$ \\
\hline & $\begin{array}{c}\text { Persicaria } \\
\text { lapathifolia }(\mathrm{L} .) \\
\text { Delarbre / NK334 }\end{array}$ & Pani ka malla & $\mathrm{H}$ & Th & Mip & Jun-Sep & Native $^{\mathrm{Co}, \mathrm{NI}}$ \\
\hline & $\begin{array}{c}\text { Persicaria } \\
\text { nepalensis } \\
\text { (Meisn.) Miyabe / } \\
\text { NK335 }\end{array}$ & Mezarh & $\mathrm{H}$ & $\mathrm{Hc}$ & Mip & Jun-Sep & Native ${ }^{\mathrm{VC}, \text { In }}$ \\
\hline & $\begin{array}{l}\text { Polygonum } \\
\text { aviculare L. / } \\
\text { NK336 }\end{array}$ & Darubra & $\mathrm{H}$ & Th & Nap & Mar-Sep & Native ${ }^{\mathrm{Co}, \mathrm{NI}}$ \\
\hline & $\begin{array}{c}\text { Polygonum } \\
\text { plebeium R. Br. / } \\
\text { NK337 }\end{array}$ & Banali & $\mathrm{H}$ & Th & Lep & May-Aug & Native $^{\mathrm{Co}, \mathrm{NI}}$ \\
\hline & $\begin{array}{l}\text { Rumex nepalensis } \\
\text { Spreng. / NK338 }\end{array}$ & Hulla & $\mathrm{H}$ & Th & Mep & Jun-Sep & Native ${ }^{\mathrm{VC}, \text { In }}$ \\
\hline & $\begin{array}{l}\text { Rumex hastatus D. } \\
\text { Don / NK339 }\end{array}$ & $\begin{array}{l}\text { Chukki, } \\
\text { Chukhri }\end{array}$ & S & $\mathrm{Ch}$ & Mip & Jun-Oct & Native $\mathrm{Co}^{\mathrm{C} \text { In }}$ \\
\hline Portulacaceae & $\begin{array}{c}\text { Portulaca } \\
\text { oleracea } \mathrm{L} . / \\
\text { NK340 }\end{array}$ & Kulfa & $\mathrm{H}$ & Th & Nap & May-Aug & Native ${ }^{\mathrm{Co}, \mathrm{NI}}$ \\
\hline \multirow[t]{4}{*}{ Primulaceae } & $\begin{array}{c}\text { Anagallis arvensis } \\
\text { var arvensis L. / } \\
\text { NK341 }\end{array}$ & Billi booti & $\mathrm{H}$ & Th & Nap & Feb-May & Native ${ }^{\mathrm{Co}, \mathrm{NI}}$ \\
\hline & $\begin{array}{c}\text { Anagallis arvensis } \\
\text { var. caerulea (L.) } \\
\text { Gouan / NK342 }\end{array}$ & Billi booti & $\mathrm{H}$ & Th & Nap & Feb-May & Native ${ }^{\mathrm{Co}, \mathrm{NI}}$ \\
\hline & $\begin{array}{c}\text { Androsace } \\
\text { rotundifolia } \\
\text { Hardwicke / } \\
\text { NK343 }\end{array}$ & Akh jarhi & $\mathrm{H}$ & $\mathrm{Hc}$ & Mip & Apr-Aug & Native ${ }^{\mathrm{Co}, \mathrm{NI}}$ \\
\hline & $\begin{array}{l}\text { Myrsine africana } \\
\text { L. / NK344 }\end{array}$ & Khukhan & S & $\mathrm{Np}$ & Nap & Mar-May & Native ${ }^{\mathrm{VC}, \mathrm{NI}}$ \\
\hline \multirow[t]{2}{*}{ Ranunculaceae } & $\begin{array}{l}\text { Clematis grata } \\
\text { Wall. / NK345 }\end{array}$ & Chitta jand & $\mathrm{C}$ & $\mathrm{L}$ & Mip & Aug-Sep & Native ${ }^{\mathrm{Co}, \mathrm{NI}}$ \\
\hline & $\begin{array}{c}\text { Ranunculus laetus } \\
\text { Wall. ex Hook. f } \\
\text { \& J.W. Thomson / } \\
\text { NK346 }\end{array}$ & $\begin{array}{c}\text { Khandbarya, } \\
\text { Chambal } \\
\text { booti }\end{array}$ & $\mathrm{H}$ & Th & Mep & Jun-Jul & Native ${ }^{\mathrm{VC}, \mathrm{NI}}$ \\
\hline Rhamnaceae & $\begin{array}{c}\text { Ziziphus jujuba } \\
\text { Mill. / NK347 }\end{array}$ & Barri & S & $\mathrm{Mc}$ & Mip & Jun-Jul & Introduced ${ }^{\mathrm{Co}, \mathrm{NI}}$ \\
\hline \multirow[t]{2}{*}{ Rosaceae } & $\begin{array}{c}\text { Agrimonia } \\
\text { eupatoria L. / } \\
\text { NK348 }\end{array}$ & Jalebi booti & $\mathrm{H}$ & Th & Mep & Jul-Aug & Introduced ${ }^{\mathrm{Ra}, \mathrm{NI}}$ \\
\hline & $\begin{array}{l}\text { Cotoneaster } \\
\text { roseus } \text { Edgew. / } \\
\text { NK349 }\end{array}$ & Loon & $\mathrm{T}$ & $\mathrm{Mc}$ & Nap & May-Jun & Native ${ }^{\text {Ra, NI }}$ \\
\hline
\end{tabular}




$$
-334 \text { - }
$$

\begin{tabular}{|c|c|c|c|c|c|c|c|}
\hline Family & $\begin{array}{c}\text { Species names } \\
\text { and Voucher No. }\end{array}$ & Local name & Habit & $\begin{array}{l}\text { Life } \\
\text { forms }\end{array}$ & $\begin{array}{c}\text { Leaf } \\
\text { spectra }\end{array}$ & Phenology & Status \\
\hline & $\begin{array}{c}\text { Duchesnea indica } \\
\text { (Andrews) Focke / } \\
\text { NK350 }\end{array}$ & Budi meva & $\mathrm{H}$ & $\mathrm{Hc}$ & Nap & Mar-Oct & Native ${ }^{\mathrm{VC}, \mathrm{NI}}$ \\
\hline & $\begin{array}{c}\text { Fragaria vesca L. } \\
\text { / NK351 }\end{array}$ & Kanechi & $\mathrm{H}$ & $\mathrm{Hc}$ & Mip & Apr-Jun & Native ${ }^{\mathrm{VC}, \mathrm{NI}}$ \\
\hline & $\begin{array}{c}\text { Prunus persica } \\
\text { (L.) Batsch / } \\
\text { NK352 }\end{array}$ & Aaroon & $\mathrm{T}$ & $\mathrm{Mc}$ & Mip & Feb-Apr & Introduced VC, In \\
\hline & $\begin{array}{c}\text { Pyrus pashia } \\
\text { Buch.-Ham. ex } \\
\text { D.Don / NK353 }\end{array}$ & Batangi & $\mathrm{T}$ & $\mathrm{Mc}$ & Mip & Apr-Jun & Native ${ }^{\mathrm{Co}, \mathrm{NI}}$ \\
\hline & $\begin{array}{c}\text { Rosa webbiana } \\
\text { Wall. ex Royle / } \\
\text { NK354 }\end{array}$ & Chahl & $\mathrm{S}$ & $\mathrm{Np}$ & Mep & Jun-Aug & Native ${ }^{\mathrm{VC}, \mathrm{NI}}$ \\
\hline & $\begin{array}{c}\text { Rubus ellipticus } \\
\text { Sm. / NK355 }\end{array}$ & Peela akhra & $\mathrm{S}$ & $\mathrm{Np}$ & Mep & Apr-Jun & Native ${ }^{\mathrm{VC}, \mathrm{NI}}$ \\
\hline & $\begin{array}{l}\text { Rubus niveus } \\
\text { Thunb. / NK356 }\end{array}$ & Pakanah & $\mathrm{S}$ & $\mathrm{Np}$ & Mep & Apr-Jun & Native VC, In \\
\hline & $\begin{array}{l}\text { Rubus ulmifolius } \\
\text { Schott / NK357 }\end{array}$ & Akhra & $\mathrm{S}$ & $\mathrm{Np}$ & Mip & Apr-Jul & Introduced VR, NI \\
\hline \multirow[t]{2}{*}{ Rubiaceae } & $\begin{array}{c}\text { Galium } \\
\text { divaricatum Pourr. } \\
\text { ex Lam. / NK358 }\end{array}$ & Boora & $\mathrm{H}$ & Th & Lep & May-Jun & Native ${ }^{\mathrm{VC}, \mathrm{NI}}$ \\
\hline & $\begin{array}{c}\text { Rubia } \\
\text { manjith Roxb. ex } \\
\text { Fleming / NK359 }\end{array}$ & Khuratan & $\mathrm{H}$ & $\mathrm{L}$ & Mip & Jun-Nov & Native ${ }^{V C, N I}$ \\
\hline \multirow[t]{2}{*}{ Rutaceae } & $\begin{array}{l}\text { Skimmia laureola } \\
\text { Franch. / NK360 }\end{array}$ & Challei & $\mathrm{S}$ & $\mathrm{Np}$ & Mip & Apr-Jun & Native ${ }^{\mathrm{VC}, \mathrm{NI}}$ \\
\hline & $\begin{array}{c}\text { Zanthoxylum } \\
\text { armatum DC. / } \\
\text { NK361 }\end{array}$ & Timbar & $S$ & $\mathrm{Mc}$ & Mip & Mar-Apr & Native ${ }^{\mathrm{Co}, \mathrm{NI}}$ \\
\hline \multirow[t]{2}{*}{ Salicaceae } & $\begin{array}{l}\text { Populus deltoides } \\
\text { Marshall / NK362 }\end{array}$ & Safeda & $\mathrm{T}$ & $\mathrm{Mp}$ & Mep & Apr-Jun & Native ${ }^{\text {Co, In }}$ \\
\hline & $\begin{array}{l}\text { Salix alba L. I } \\
\text { NK363 }\end{array}$ & Beesa & $\mathrm{T}$ & $\mathrm{Mp}$ & Mip & Apr-May & Introduced Ra, NI \\
\hline \multirow[t]{2}{*}{ Sapindaceae } & $\begin{array}{l}\text { Dodonaea viscosa } \\
\text { (L.) Jacq. / NK364 }\end{array}$ & Sanatha & S & $\mathrm{Np}$ & Mip & Jan-Mar & Native ${ }^{\mathrm{VC}, \text { In }}$ \\
\hline & $\begin{array}{c}\text { Aesculus indica } \\
\text { (Wall. ex } \\
\text { Cambess.) Hook. / } \\
\text { NK365 }\end{array}$ & Bankhor & $\mathrm{T}$ & Ms & Mep & Apr-May & Native ${ }^{R a, N I}$ \\
\hline Saxifragaceae & $\begin{array}{c}\text { Bergenia ciliata } \\
\text { (Haw.) Sternb. / } \\
\text { NK366 }\end{array}$ & $\begin{array}{l}\text { Batt peya, } \\
\text { Zakham e } \\
\text { hayaat }\end{array}$ & $\mathrm{H}$ & $\mathrm{Hc}$ & Mep & Mar-May & Native ${ }^{R a, N I}$ \\
\hline Scrophulariaceae & $\begin{array}{c}\text { Verbascum } \\
\text { thapsus L. / } \\
\text { NK367 }\end{array}$ & $\begin{array}{c}\text { Jangli } \\
\text { tambaku }\end{array}$ & $\mathrm{H}$ & $\mathrm{Th}$ & Mep & Jun-Aug & Native ${ }^{\mathrm{Co}, \mathrm{In}}$ \\
\hline Simaroubaceae & $\begin{array}{c}\text { Ailanthus } \\
\text { altissima (Mill.) } \\
\text { Swingle / NK368 }\end{array}$ & Darawiya & $\mathrm{T}$ & $\mathrm{Mp}$ & Map & May-Jun & Introduced VC, In \\
\hline
\end{tabular}




\begin{tabular}{|c|c|c|c|c|c|c|c|}
\hline Family & $\begin{array}{c}\text { Species names } \\
\text { and Voucher No. }\end{array}$ & Local name & Habit & $\begin{array}{l}\text { Life } \\
\text { forms }\end{array}$ & $\begin{array}{c}\text { Leaf } \\
\text { spectra }\end{array}$ & Phenology & Status \\
\hline \multirow[t]{7}{*}{ Solanaceae } & $\begin{array}{c}\text { Datura } \\
\text { stramonium L. / } \\
\text { NK369 }\end{array}$ & Datura & $\mathrm{H}$ & $\mathrm{Np}$ & Mep & Jun-Jul & Introduced VC, In \\
\hline & $\begin{array}{l}\text { Physalis minima } \\
\text { L. / NK370 }\end{array}$ & Jangli tamatar & $\mathrm{H}$ & $\mathrm{Th}$ & Mip & Aug-Oct & Introduced ${ }^{\mathrm{Co}, \mathrm{NI}}$ \\
\hline & $\begin{array}{c}\text { Solanum } \\
\text { americanum Mill. } \\
\text { / NK371 }\end{array}$ & Kach mach & $\mathrm{H}$ & $\mathrm{Th}$ & Mip & Jun-Oct & Introduced $^{\mathrm{Ra}, \mathrm{NI}}$ \\
\hline & $\begin{array}{c}\text { Solanum } \\
\text { pseudocapsicum } \\
\text { L. / NK372 }\end{array}$ & Marcholi & $\mathrm{S}$ & $\mathrm{Th}$ & Mip & Apr-Jul & Introduced ${ }^{\mathrm{Ra}, \mathrm{NI}}$ \\
\hline & $\begin{array}{c}\text { Solanum } \\
\text { surattense Burm. } \\
\text { f. / NK373 }\end{array}$ & Kandiari & $\mathrm{H}$ & $\mathrm{Hc}$ & Mip & Whole year & Native ${ }^{C o, \text { In }}$ \\
\hline & $\begin{array}{l}\text { Solanum villosum } \\
\text { Mill. / NK374 }\end{array}$ & Kach mach & $\mathrm{H}$ & Th & Mip & Jul-Sep & Native ${ }^{\mathrm{Co}, \mathrm{NI}}$ \\
\hline & $\begin{array}{c}\text { Withania } \\
\text { somnifera }(\mathrm{L} .) \\
\text { Dunal / NK375 }\end{array}$ & Aksoon & $\mathrm{H}$ & $\mathrm{Ch}$ & Mep & Whole year & Native ${ }^{R a, N I}$ \\
\hline \multirow[t]{3}{*}{ Verbenaceae } & $\begin{array}{c}\text { Glandularia } \\
\text { aristigera } \\
\text { (S.Moore) Tronc. / } \\
\text { NK376 }\end{array}$ & Unavailable & $\mathrm{H}$ & $\mathrm{Th}$ & Lep & Sep-Apr & Introduced VR, NI \\
\hline & $\begin{array}{c}\text { Lantana camara } \\
\text { L. / NK377 }\end{array}$ & Panj phulli & $\mathrm{S}$ & $\mathrm{Np}$ & Mip & Whole year & Introduced ${ }^{\mathrm{Co}, \text { In }}$ \\
\hline & $\begin{array}{c}\text { Verbena } \\
\text { officinalis L. / } \\
\text { NK378 }\end{array}$ & Pamukh & $\mathrm{H}$ & Th & Mip & Jun-Sep & Native Ra, NI \\
\hline \multirow[t]{2}{*}{ Violaceae } & $\begin{array}{l}\text { Viola canescens } \\
\text { Wall. / NK379 }\end{array}$ & Gul naqsh & $\mathrm{H}$ & $\mathrm{Hc}$ & Mip & Mar-Jun & Native ${ }^{\mathrm{VC}, \mathrm{NI}}$ \\
\hline & $\begin{array}{c}\text { Viola odorata L. / } \\
\text { NK380 }\end{array}$ & Gul naqsh & $\mathrm{H}$ & $\mathrm{Hc}$ & Mip & Mar-Jul & Introduced ${ }^{R a, N I}$ \\
\hline Vitaceae & $\begin{array}{c}\text { Vitis vinifera L. / } \\
\text { NK381 }\end{array}$ & Daakh & $\mathrm{C}$ & $\mathrm{L}$ & Mep & May-Jul & Introduced VR, NI \\
\hline \multirow[t]{3}{*}{ Urticaceae } & $\begin{array}{c}\text { Debregeasia } \\
\text { saeneb (Forssk.) } \\
\text { Hepper \& J.R.I. } \\
\text { Wood / NK382 }\end{array}$ & Sindhari & $\mathrm{S}$ & $\mathrm{Np}$ & Mep & Mar-Jun & Native ${ }^{\mathrm{Co}, \mathrm{NI}}$ \\
\hline & $\begin{array}{c}\text { Parietaria judaica } \\
\text { L. / NK383 }\end{array}$ & Unavailable & $\mathrm{H}$ & $\mathrm{Th}$ & Mip & Jul-Aug & Native VR, NI \\
\hline & $\begin{array}{c}\text { Urtica dioica } \mathrm{L} . / \\
\text { NK384 }\end{array}$ & Bichu booti & $\mathrm{H}$ & G & Mip & May-Sep & Native Ra, NI \\
\hline
\end{tabular}

Legend: *Habit: $\mathrm{H}=$ Herb, $\mathrm{S}=$ Shrub, $\mathrm{T}=$ Tree, $\mathrm{C}=$ Climber; $* *$ Life forms: $\mathrm{Mp}=$ Megaphanerophyte, $\mathrm{Ms}=$ Mesophanerophyte, $\mathrm{Mc}=$ Microphanerophyte, $\mathrm{Np}=$ Nanophanerophyte, $\mathrm{Ch}=$ Chaemephyte, $\mathrm{Hc}=$ Hemicryptophyte, $\mathrm{G}=$ Geophyte, Th= Therophyte; ***Leaf spectra: Lep= Leptophyll, Nap= Nanophyll, Mip= Microphyll, Mep= Mesophyll, Map= Macrophyll; ****Status: VC=Very Common (Frequency of occurrence $=.75-100 \%$ ), $\mathrm{Co}=$ Common (Frequency of occurrence $=.50-75 \%$ ), Ra=Rare (Frequency of occurrence $=.25-50 \%$ ), VR=Very Rare (Frequency of occurrence $=.0-25 \%$ ), IN=Invassive, $\mathrm{NI}=$ Noninvassive. 
Supplementary Data Table 2. Monthly temporal climatic variations (Mean \pm SD (Min-Max)) in the study area from March-2015 to February-2018 (3 years)

\begin{tabular}{|c|c|c|c|c|c|c|c|c|}
\hline Months & $\begin{array}{c}\text { Min. Temp } \\
\left({ }^{\circ} \mathrm{C}\right) \\
\end{array}$ & $\begin{array}{c}\text { Max. Temp } \\
\left({ }^{\circ} \mathrm{C}\right) \\
\end{array}$ & PPT (mm) & $\begin{array}{c}\text { Spe. Hum. } \\
(\mathrm{g} / \mathrm{kg})\end{array}$ & $\begin{array}{l}\text { Soil Moist. } \\
\text { (frac.) }\end{array}$ & $\begin{array}{c}\text { Wind Speed } \\
(\mathrm{m} / \mathrm{sec})\end{array}$ & $\begin{array}{c}\text { Shortwave } \\
\text { Rad. }\left(\mathbf{W} / \mathbf{M}^{2}\right) \\
\end{array}$ & $\begin{array}{c}\text { Longwave } \\
\text { Rad. }\left(\mathrm{W} / \mathbf{M}^{2}\right) \\
\end{array}$ \\
\hline January & $\begin{array}{l}1.1 \pm 0.99 \\
(-0.35-2)\end{array}$ & $\begin{array}{l}12.87 \pm 2.99 \\
(9.68-16.4)\end{array}$ & $\begin{array}{c}107.52 \pm 104.55 \\
(4.26-264.45)\end{array}$ & $\begin{array}{c}2.8 \pm 0.84 \\
(1.7-3.59)\end{array}$ & $\begin{array}{c}0.32 \pm 0.04 \\
(0.27-0.34)\end{array}$ & $\begin{array}{c}3.27 \pm 0.23 \\
(3.03-3.52)\end{array}$ & $\begin{array}{c}13.95 \pm 2.87 \\
(10.62-17.11)\end{array}$ & $\begin{array}{c}341.78 \pm 8.25 \\
(331.65-350.65)\end{array}$ \\
\hline February & $\begin{array}{c}2.26 \pm 1.26 \\
(0.04-2.99)\end{array}$ & $\begin{array}{c}14.33 \pm 2.81 \\
(10.16-17.18)\end{array}$ & $\begin{array}{l}198.99 \pm 132.14 \\
(69.82-415.55)\end{array}$ & $\begin{array}{c}3.97 \pm 0.48 \\
(3.36-4.47)\end{array}$ & $\begin{array}{l}0.34 \pm 0.03 \\
(0.3-0.38)\end{array}$ & $\begin{array}{c}3.59 \pm 0.14 \\
(3.42-3.79)\end{array}$ & $\begin{array}{c}16.38 \pm 2.92 \\
(13.89-20.85)\end{array}$ & $\begin{array}{c}349.92 \pm 9.09 \\
(334.85-357.26) \\
\end{array}$ \\
\hline March & $\begin{array}{c}5.14 \pm 1.43 \\
(3.64-6.95)\end{array}$ & $\begin{array}{c}18.01 \pm 2.5 \\
(16.35-22.35)\end{array}$ & $\begin{array}{l}251.54 \pm 156.91 \\
(93.49-508.13)\end{array}$ & $\begin{array}{c}5.17 \pm 0.66 \\
(4.23-6.01)\end{array}$ & $\begin{array}{c}0.36 \pm 0.03 \\
(0.31-0.38)\end{array}$ & $\begin{array}{c}3.54 \pm 0.14 \\
(3.36-3.71)\end{array}$ & $\begin{array}{c}19.72 \pm 2.14 \\
(18.03-23.06)\end{array}$ & $\begin{array}{c}368.03 \pm 10.25 \\
(361.12-384.95)\end{array}$ \\
\hline April & $\begin{array}{l}9.29 \pm 0.43 \\
(8.8-9.86)\end{array}$ & $\begin{array}{c}25.09 \pm 1.35 \\
(22.75-26.01)\end{array}$ & $\begin{array}{c}193.26 \pm 80.56 \\
(118.46-284.41)\end{array}$ & $\begin{array}{c}6.71 \pm 0.62 \\
(6.27-7.68)\end{array}$ & $\begin{array}{c}0.35 \pm 0.02 \\
(0.33-0.38)\end{array}$ & $\begin{array}{c}3.48 \pm 0.22 \\
(3.22-3.79)\end{array}$ & $\begin{array}{c}26.8 \pm 1.38 \\
(25.27-28.62)\end{array}$ & $\begin{array}{c}399.14 \pm 4.51 \\
(391.62-402.74)\end{array}$ \\
\hline May & $\begin{array}{c}13.23 \pm 0.84 \\
(12.32-14.24)\end{array}$ & $\begin{array}{c}30.09 \pm 0.65 \\
(29.38-30.98)\end{array}$ & $\begin{array}{c}106.65 \pm 41.6 \\
(60.53-163.46)\end{array}$ & $\begin{array}{c}6.93 \pm 0.84 \\
(6.14-8.09)\end{array}$ & $\begin{array}{c}0.33 \pm 0.01 \\
(0.32-0.34)\end{array}$ & $\begin{array}{l}3.47 \pm 0.14 \\
(3.27-3.6)\end{array}$ & $\begin{array}{c}30.78 \pm 1.11 \\
(28.85-31.68)\end{array}$ & $\begin{array}{c}427.15 \pm 4.44 \\
(422.75-434.19)\end{array}$ \\
\hline June & $\begin{array}{c}16.76 \pm 1 \\
(15.58-17.86)\end{array}$ & $\begin{array}{c}33.04 \pm 1.11 \\
(31.32-34.04)\end{array}$ & $\begin{array}{c}68.56 \pm 36.94 \\
(32.69-117.61)\end{array}$ & $\begin{array}{c}8.1 \pm 1.45 \\
(6.24-9.61) \\
\end{array}$ & $\begin{array}{c}0.3 \pm 0.01 \\
(0.29-0.31)\end{array}$ & $\begin{array}{c}3.38 \pm 0.26 \\
(3.19-3.74)\end{array}$ & $\begin{array}{c}32.1 \pm 1.11 \\
(30.34-33.33)\end{array}$ & $\begin{array}{c}450.29 \pm 6.39 \\
(440.07-456.16)\end{array}$ \\
\hline July & $\begin{array}{c}18.25 \pm 0.38 \\
(17.88-18.83)\end{array}$ & $\begin{array}{c}29.12 \pm 0.97 \\
(27.66-30.25)\end{array}$ & $\begin{array}{c}481.82 \pm 100.86 \\
(381.29-625.72)\end{array}$ & $\begin{array}{c}14.78 \pm 1.09 \\
(13.28-16.31)\end{array}$ & $\begin{array}{c}0.36 \pm 0.02 \\
(0.35-0.38)\end{array}$ & $\begin{array}{l}2.32 \pm 0.24 \\
(1.96-2.6)\end{array}$ & $\begin{array}{c}31.1 \pm 1.6 \\
(29.36-33.23)\end{array}$ & $\begin{array}{c}440.6 \pm 3.19 \\
(436.13-444.57)\end{array}$ \\
\hline August & $\begin{array}{c}16.9 \pm 0.43 \\
(16.5-17.59)\end{array}$ & $\begin{array}{c}28.38 \pm 0.77 \\
(27.21-29.22)\end{array}$ & $\begin{array}{c}353.7 \pm 123.42 \\
(200.57-528.17)\end{array}$ & $\begin{array}{c}14.3 \pm 0.97 \\
(13.02-15.09)\end{array}$ & $\begin{array}{l}0.39 \pm 0.02 \\
(0.37-0.4)\end{array}$ & $\begin{array}{c}2.41 \pm 0.14 \\
(2.25-2.61)\end{array}$ & $\begin{array}{c}30.29 \pm 1.09 \\
(28.79-31.37)\end{array}$ & $\begin{array}{c}431.58 \pm 2.57 \\
(428.56-434.94)\end{array}$ \\
\hline September & $\begin{array}{c}14.3 \pm 0.83 \\
(13.17-15.37)\end{array}$ & $\begin{array}{c}28.55 \pm 0.53 \\
(28.12-29.42)\end{array}$ & $\begin{array}{c}64.13 \pm 15.82 \\
(45.86-89.15)\end{array}$ & $\begin{array}{c}9.2 \pm 1.2 \\
(7.8-10.33)\end{array}$ & $\begin{array}{c}0.33 \pm 0.01 \\
(0.32-0.35)\end{array}$ & $\begin{array}{c}2.84 \pm 0.08 \\
(2.75-2.94)\end{array}$ & $\begin{array}{c}28.48 \pm 0.42 \\
(28.19-29.16)\end{array}$ & $\begin{array}{c}421.79 \pm 3 \\
(417.79-424.79) \\
\end{array}$ \\
\hline October & $\begin{array}{l}10.46 \pm 1.14 \\
(8.92-11.8)\end{array}$ & $\begin{array}{c}25.7 \pm 2.15 \\
(24.06-28.3)\end{array}$ & $\begin{array}{c}53.87 \pm 56.48 \\
(1.23-133.12)\end{array}$ & $\begin{array}{c}4.89 \pm 0.85 \\
(3.85-5.68)\end{array}$ & $\begin{array}{c}0.31 \pm 0.02 \\
(0.29-0.33)\end{array}$ & $\begin{array}{c}3.1 \pm 0.14 \\
(2.94-3.31)\end{array}$ & $\begin{array}{c}22.63 \pm 1.84 \\
(20.39-24.59)\end{array}$ & $\begin{array}{c}399.22 \pm 8.82 \\
(389.85-410.34)\end{array}$ \\
\hline November & $\begin{array}{c}5.83 \pm 0.98 \\
(5.01-7.46)\end{array}$ & $\begin{array}{c}19 \pm 2.45 \\
(16.81-22.08)\end{array}$ & $\begin{array}{c}60.14 \pm 47.82 \\
(10.37-117.96)\end{array}$ & $\begin{array}{c}3.47 \pm 0.9 \\
(2.46-4.28)\end{array}$ & $\begin{array}{c}0.31 \pm 0.04 \\
(0.27-0.35)\end{array}$ & $\begin{array}{c}3.5 \pm 0.29 \\
(3.02-3.72)\end{array}$ & $\begin{array}{c}16.05 \pm 2.24 \\
(14.07-19.14)\end{array}$ & $\begin{array}{c}367.9 \pm 8.17 \\
(361-379.58)\end{array}$ \\
\hline December & $\begin{array}{c}2.87 \pm 1.47 \\
(1.74-5.35) \\
\end{array}$ & $\begin{array}{c}16.17 \pm 2.38 \\
(14.63-20.33) \\
\end{array}$ & $\begin{array}{c}37.47 \pm 23.2 \\
(2.79-55.87) \\
\end{array}$ & $\begin{array}{l}2.44 \pm 0.45 \\
(1.8-3.03)\end{array}$ & $\begin{array}{c}0.3 \pm 0.03 \\
(0.27-0.33) \\
\end{array}$ & $\begin{array}{c}3.34 \pm 0.25 \\
(3.08-3.74) \\
\end{array}$ & $\begin{array}{c}15.54 \pm 0.93 \\
(14.71-17.02) \\
\end{array}$ & $\begin{array}{c}352.41 \pm 9.26 \\
(345.56-368.11) \\
\end{array}$ \\
\hline
\end{tabular}

Legends: Min. Temp = Mean minimum temperature; Max. Temp. = Mean maximum temperature; PPT = Mean precipitation; Spe. Hum. = Mean specific humidity;

Soil Moist. = Mean soil moisture (below 5cm); Shortwave/Longwave Rad. = Mean shortwave/longwave radiations 
Supplementary Data Table 3. GPS data of study locations

\begin{tabular}{|c|c|c|c|}
\hline No. & Study location & Longitude (East) & Latitude (North) \\
\hline 1 & Arja1 & 73.66294867 & 33.97807 \\
\hline 2 & Arja2 & 73.67143619 & 33.98500396 \\
\hline 3 & Azam Nagar1 & 73.58753339 & 34.02468598 \\
\hline 4 & Azam Nagar2 & 73.59279973 & 34.00840741 \\
\hline 5 & Benj1 & 73.684812 & 34.045877 \\
\hline 6 & Benj2 & 73.68481246 & 34.0558 \\
\hline 7 & Chamyati1 & 73.51381315 & 34.0590691 \\
\hline 8 & Chamyati2 & 73.52695797 & 34.06288953 \\
\hline 9 & Chamyati3 & 73.54115746 & 34.06611085 \\
\hline 10 & Dhirkot1 & 73.57682243 & 34.03068903 \\
\hline 11 & Dhirkot2 & 73.57880889 & 34.02406129 \\
\hline 12 & Ghaziabad1 & 73.629676 & 33.991651 \\
\hline 13 & Ghaziabad2 & 73.62939449 & 33.98326068 \\
\hline 14 & Kanyati1 & 73.58634701 & 34.07441619 \\
\hline 15 & Kanyati2 & 73.57519198 & 34.0691501 \\
\hline 16 & Kohala1 & 73.5067886 & 34.09299635 \\
\hline 17 & Kohala2 & 73.5143939 & 34.09728174 \\
\hline 18 & Munasa1 & 73.51824205 & 34.08089177 \\
\hline 19 & Munasa2 & 73.52186825 & 34.08944362 \\
\hline 20 & Neela Butt1 & 73.591492 & 33.999812 \\
\hline 21 & Neela Butt2 & 73.57714147 & 33.99911363 \\
\hline 22 & North1 & 73.53210804 & 34.12355846 \\
\hline 23 & North2 & 73.5380138 & 34.11987237 \\
\hline 24 & Padder Mastoo1 & 73.63636299 & 34.0177996 \\
\hline 25 & Padder Mastoo2 & 73.65317164 & 34.02406422 \\
\hline 26 & Sanghar Bathara1 & 73.54928172 & 34.0982717 \\
\hline 27 & Sanghar Bathara2 & 73.55761023 & 34.09329579 \\
\hline 28 & Sanghar Bathara3 & 73.57150737 & 34.089422 \\
\hline 29 & South1 & 73.56751493 & 33.93229927 \\
\hline 30 & South2 & 73.57392639 & 33.91939993 \\
\hline 31 & South3 & 73.57610508 & 33.940425 \\
\hline 32 & South4 & 73.5779541 & 33.97623264 \\
\hline 33 & Sudhan Gala1 & 73.67467431 & 34.00685613 \\
\hline 34 & Sudhan Gala2 & 73.66437067 & 34.00651954 \\
\hline 35 & Taal Gayat1 & 73.61570527 & 34.02274768 \\
\hline 36 & Taal Gayat2 & 73.60374374 & 34.03465304 \\
\hline 37 & Timroota Pail1 & 73.62656789 & 34.00408794 \\
\hline 38 & Timroota Pail2 & 73.60862241 & 33.99616598 \\
\hline
\end{tabular}

